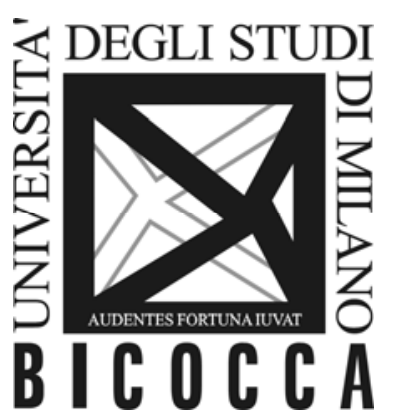

DEPARTMENT OF ECONOMICS,
MANAGEMENT AND STATISTICS
UNIVERSITY OF MILAN - BICOCCA

DEMS WORKING PAPER SERIES

\title{
International Outsourcing versus FDI under Contractual Incompleteness
}

\author{
Valeria Gattai
}

No. 237 -March 2013

Dipartimento di Economia, Metodi Quantitativi e Strategie di Impresa Università degli Studi di Milano - Bicocca

http://dems.unimib.it/ 


\title{
International Outsourcing versus FDI under Contractual Incompleteness
}

\author{
Valeria Gattai ${ }^{*}$
}

\begin{abstract}
This paper empirically analyzes the boundaries of a large sample of Italian multinational enterprises, with firm-level data from Capitalia, AIDA and Centrale dei Bilanci. Within the broad array of feasible contracts in a foreign country, we focus on the trade-off between international outsourcing and Foreign Direct Investment (FDI), in a context of contractual incompleteness. Probit estimates reveal that Italian enterprises operating in highly relation-specific environments are more prone to international outsourcing than FDI, consistently with recent theoretical contributions on the topic. Results are robust to different specifications and alternative measures of contractual incompleteness and international outsourcing.
\end{abstract}

JEL: $F 23, C 25$

Keywords: FDI, international outsourcing, contractual incompleteness, Italy

\footnotetext{
* University of Milan Bicocca, Department of Economics, Piazza Ateneo Nuovo 1, 20126 Milan (Italy), Email: valeria.gattai@unimib.it, Phone: +39 (0)2 64483224.
} 


\section{Introduction}

This paper empirically analyzes the boundaries of a large sample of Italian Multinational Enterprises (MNEs), with firm-level data from Capitalia, AIDA and Centrale dei Bilanci. Within the broad array of feasible contracts in a foreign country, we focus on the tradeoff between international outsourcing and Foreign Direct Investment (FDI) ${ }^{1}$, in a context of contractual incompleteness (CI).

When expanding abroad, firms take crucial decisions about the most appropriate mode of entry into a foreign country. This implies a critical consideration of ownership and location strategies to define which activities are better performed within firms' boundaries and which are better externalized; which activities call for a domestic location and which for a foreign one.

For the sake of simplicity, consider a multinational enterprise that is willing to produce a final good abroad; assume that final good production requires two activities - input manufacturing and final good processing - and that the MNE is responsible for processing. How does it secure the needed components? It is clear that either the multinational can manufacture inputs within its boundaries or it can purchase them from an independent supplier: this is what we call ownership decision. Moreover, the MNE can decide to make-or-buy inputs either in the home or in the host country: this is the location choice as referred to in the present paper. The boundaries of the multinational thus result from the intersection between ownership and location concerns, as depicted in Figure 1. Depending on whether the input supplier is a domestic or a foreign enterprise, and whether it belongs to the MNE or not, four contractual arrangements may emerge: domestic integration, FDI, domestic outsourcing, and international outsourcing (Antras and Helpman 2004). For the purpose of the present research, we are particularly interested in the foreign dimension of the make-or-buy trade-off. Therefore, when

\footnotetext{
${ }^{1}$ Consistently with the IMF/OECD definitions, we call FDI an investment in a foreign company in which the investor owns at least 10 percent of the ordinary shares, undertaken with the objective of establishing a lasting interest in the country, a long-term relationship, and a significant influence on the management of the firm (IMF 1993; OECD 1996). In our terminology, multinational enterprises are those engaged with international operations of any kind.
} 
discussing about MNEs' boundaries, we focus on the relative profitability of foreign direct investment versus international outsourcing.

Figure 1: The boundaries of the Multinational Enterprise

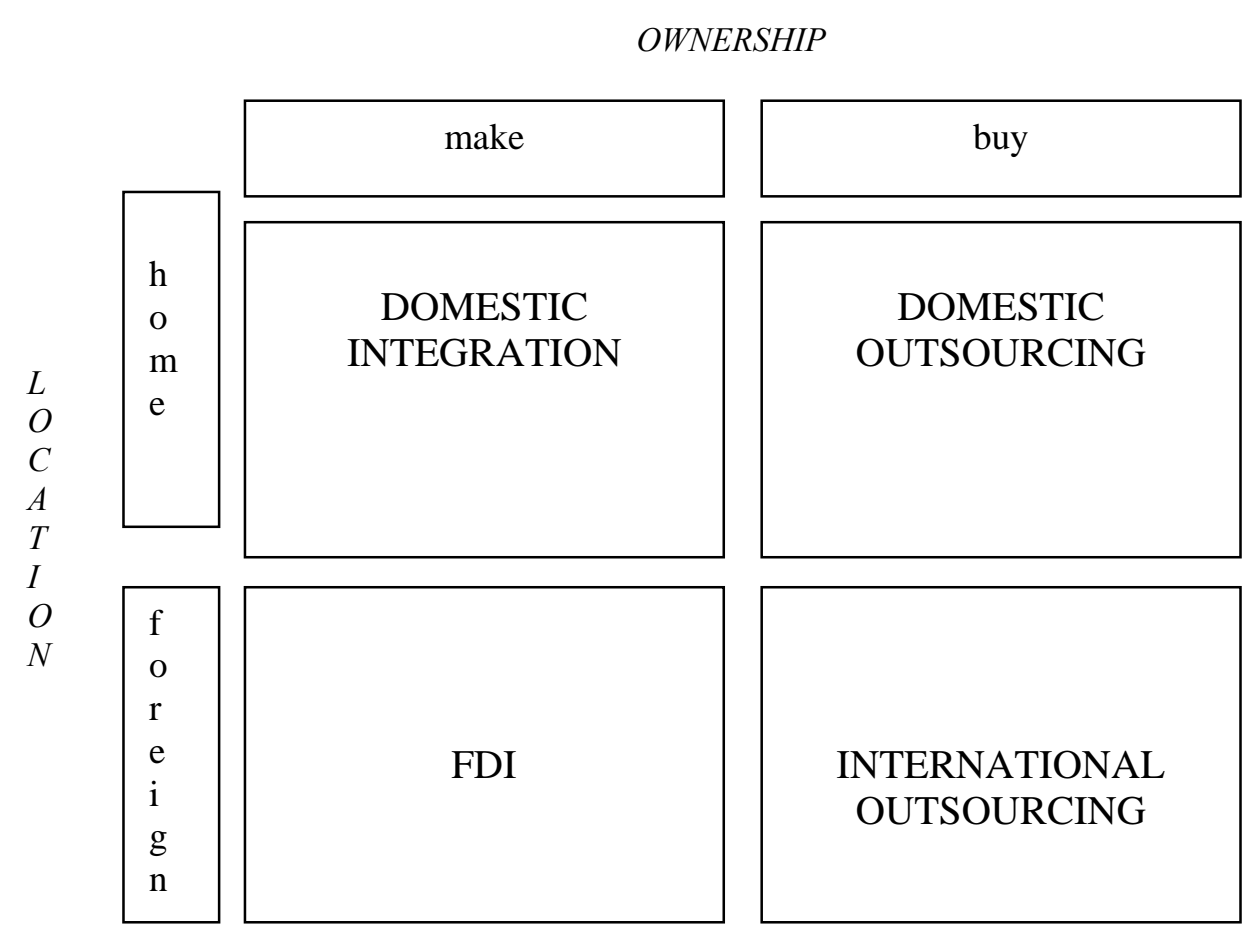

This is quite a novel and urgent issue in International Economics, both from an academic and a policy perspective, Yet, more than 40 percent of US imports of goods has taken place within the boundaries of multinational enterprises since the 1990s (Zeile 1997), and every third transaction in the world now occurs intra-firm (Antras 2003; Helpman 2006; Bernard et al 2010).

What accounts for these changes in the nature of trade and investment patterns?

In theoretical terms, one candidate explanation behind the international outsourcing/FDI trade-off stems from the wish to mitigate hold-up concerns in a context of contractual incompleteness. According to Grossman and Helpman (2003), Antras (2003), Antras and Helpman (2004), and Ottaviano and Turrini (2007), an increase in CI affects the relative prevalence of the two organizational forms, shifting MNEs towards foreign direct investment. On the contrary, the most recent contribution due to Antras and Helpman (2008) reverts this finding by showing that greater contractual incompleteness may 
favour either international outsourcing or FDI depending on whether relation-specificity characterizes the input controlled by the final good producer or the input supplier. Since the theory does not provide any conclusive result about the sign of CI in shaping the boundaries of the MNE, there is ample room for empirical investigation. However, to the best of our knowledge, there have been only a few attempts at testing the impact of contractual incompleteness on firms' organizational decisions, and results are not clearcut. This probably depends on the lack of suitable data and the difficulties to find good proxies for CI. For instance, Antras (2003), Yeaple (2006), Tomiura (2007), Nunn and Trefler (2008), and Corcos et al. (2008) provide some evidence on the topic ${ }^{2}$; nonetheless, their approach is quite indirect, since no measure of CI is included in the econometric analysis. Moreover, their findings are not conclusive, and support to the models is rather weak.

In light of the above discussion, this paper is intended to add some empirical evidence on the topic, to see a) whether contractual incompleteness plays any role in orienting Italian firms' decision of FDI versus international outsourcing, and b) whether its impact on FDI is positive (as suggested by Antras 2003; Antras and Helpman 2004, 2008; Grossman and Helpman 2003; Ottaviano and Turrini 2007) or negative (as compatible with Antras and Helpman 2008). In doing so, we aim at contributing to the existing empirical literature both in terms of the specification and the type of data. As for the former, we build alternative measures of $\mathrm{CI}$ and include them as core regressors in the international outsourcing equation, to properly deal with their sign. As for the latter, we provide fresh evidence of Italian operations worldwide, differently from a literature very much focused on the US.

Our estimates reveal that Italian enterprises operating in highly relation-specific environments are more prone to international outsourcing than FDI, meaning that CI has a negative effect on foreign direct investment. This is robust to different econometric specifications and alternative measures of CI and international outsourcing.

The rest of the paper is organized as follows. Section 2 briefly reviews the literature on the international outsourcing/FDI trade-off under contractual incompleteness, to discuss

\footnotetext{
${ }^{2}$ A complementary perspective is offered by Bernard et al (2010) that study the importance of product contractibility and governance quality in explaining intra-firm trade.
} 
the theoretical and empirical foundations of hold-up and CI. Section 3 is entirely devoted to the empirical analysis, with a detailed description of the data, the econometric specification, and our main findings. Section 4 then concludes and sets future lines of research.

\section{Literature review}

Theories on the boundaries of the multinational enterprise can be grouped according to three strands, namely: Dissipation of Intangible Asset, Agency Costs and Theory of the firm-based contributions ${ }^{3}$. While the first two approaches investigate the choice of FDI versus some forms of international partnering, such as joint-venture or licensing agreements, the third deals with the trade-off between foreign direct investment and international outsourcing. Hence, for the purpose of the present research, we restrict attention to the theory of the firm-based contributions, as they provide the analytical framework to interpret our econometric results.

We believe this is a very promising and innovative perspective in that it studies the makeor-buy decision, at an international level, through the opening up of the "black box", traditionally explored by the theorists of the firm, and the simultaneous endogenization of the market environment, as in the International Economics tradition. In particular, three paradigms - the Grossman-Hart-Moore (G-H-M) treatment of hold-up and contractual incompleteness, the Holmstrom-Milgrom view of the firm as an incentive system, and the Aghion-Tirole conceptualization of formal and real authority in organizations - have been embedded in industry and general equilibrium models to explain the boundaries of multinational enterprises.

Our empirical analysis grounds on the G-H-M paradigm, because it is the most mature, in terms of the numerousness and the complexity of the applications to foreign direct investment. Therefore, in what follows, we review the main models dealing with the international outsourcing/FDI trade-off, based on hold-up and contractual incompleteness. This literature builds on transaction cost economics ${ }^{4}$ : formerly spelled by Coase (1937), and lately operationalized by Williamson (1975), it was fruitfully applied

\footnotetext{
${ }^{3}$ For a survey, see Markusen (1995) and Barba Navaretti and Venables (2004), Gattai (2006).

${ }^{4}$ For a survey about transaction cost economics, see Tadelis and Williamson (2012).
} 
to the international context since 1980s to study the governance of multinational enterprises (Teece 1986).

To have a rough idea about CI, which is of primary importance for our purposes, consider the economic exchange between two parties, called input supplier and final good producer. In an ideal world, their relationship would be easily governed by a complete contract, namely a contract that specifies all the relevant contingencies that may affect the contractual relationship. On the contrary, real world is the land of incomplete contracts that turn out to be vague or silent on a number of key features (Tirole 1999) and have gaps, missing provisions or ambiguities (Hart 1995). CI becomes a particularly serious problem when the contracting parties, although independent, are linked by some relationspecific investment, which is valuable only inside that specific exchange. In this case, each of them may fear that, after making the relation-specific investment, the other party denies the due payment claiming that some contingencies, uncovered by the contract, have occurred. Given that their investment is already sunk, at the renegotiation stage, firms fear to be held-up and they tend to underinvest. Grout (1984), Grossman and Hart (1986) and Hart and Moore (1990) formalize the hold-up mechanism described above and show that integration is a possible solution against suboptimal investment.

This intuition is extended to the international context in Grossman and Helpman (2003), Antras (2003), Ottaviano and Turrini (2007), and Antras and Helpman (2004, 2008).

A maintained framework across these models is that the MNE, located in the North, is the final good producer, and it has two options to secure the needed components: it can either make them within the boundaries of an affiliate in the South (FDI) or buy them from an independent local supplier (international outsourcing). Moreover, production of final goods requires relation-specific investment in manufacturing components, which may lead to hold-up concerns.

What differs, across the above mentioned papers, is instead the type of sourcing strategies they analyze, and some ancillary assumptions regarding the economic framework.

As for the sourcing strategies, Antras (2003), Grossman and Helpman (2003), and Ottaviano and Turrini (2007) focus only on the relative profitability of FDI versus international outsourcing ${ }^{5}$. They show that the MNEs' make-or-buy decision results, at a

\footnotetext{
${ }^{5}$ See the bottom panel of Figure 1.
} 
preliminary stage, from the standard trade-off between governance and transaction costs. Indeed, a vertically integrated firm is less efficient in intermediate good production, and it entails higher costs of entry and product design, while a pair of specialized producers suffers from transaction costs whenever CI is assumed and relation-specific investment is needed. The same result holds in Antras and Helpman (2004), even though they offer a more complete characterization of MNEs' sourcing strategies, by considering ownership and location concerns in a unitary framework ${ }^{6}$. Their analysis is then generalized in Antras and Helpman (2008) that allow for different degrees of contractual incompleteness, under the partial contracting framework due to Acemoglu et al. (2007). To the best of our knowledge, this is the first paper on the international outsourcing/FDI trade-off in which CI is not considered as a binary indicator - either characterizing or not the economic relation between the multinational and the local enterprise - but rather as a continuous variable that captures the extent of hold-up problems. Under this assumption, Antras and Helpman (2008) prove that contractual incompleteness generates complex effects that can be grouped under a standard and a surprise result. The standard result is that an increase in CI discourages outsourcing; this is consistent with the previous papers and it holds when the decline in contractibility refers to the input provided by the MNE. The surprise result is instead that an increase in CI favours outsourcing; this strongly contradicts the existing literature, and it holds when the decline in contractibility refers to the input provided by the independent firm. As explained in the paper, what matters is the output elasticity with respect to non-contractible inputs. Firms should be more willing to accept a lower incentive for the supplier that comes along with integration, if the share of non-contractible inputs - and thus the output elasticity with respect to them - is small. To summarize, by allowing for different degrees of contractual incompleteness, this paper proves that improvements in contractibility of inputs - namely a decrease in CI - can either increase or decrease international outsourcing relative to FDI, while it always increases international outsourcing in the papers reviewed before.

As discussed above, the contributions mentioned in this section differ not only in terms of the sourcing strategies they analyze, but also in terms of the ancillary assumptions regarding the economic framework. This allows the various authors to study the effect of

\footnotetext{
${ }^{6}$ They study all contractual arrangements displayed in Figure 1.
} 
a number of additional variables on the choice between FDI and international outsourcing. For instance, Grossman and Helpman (2003) derive equilibria in which some firms outsource to the South and some other engage in FDI, depending on the distance between the input supplier and the final good producer in the space of characteristics: the more they are close to each other, the more likely the outsourcing solution. Antras (2003) finds that capital-intensive goods are transacted within the boundaries of multinational enterprises, while labour-intensive goods tend to be traded at arm's length; moreover, transactions with capital-abundant countries take place through FDI, while transactions with capital-scarce countries are arranged under international outsourcing. In a partially different framework, Ottaviano and Turrini (2007) show that trade costs crucially affect MNEs' choice of export versus local production and, for firms already engaged in local production, the choice of integration versus outsourcing. If trade costs are high, the proximity-concentration trade-off ${ }^{7}$ dominates and local production is preferred to export. If they are low, the contractual incompleteness trade-off ${ }^{8}$ prevails meaning that, on the one hand, export becomes more appealing but, on the other hand, the outside option from FDI strengthens, making outsourcing more profitable. Hence, if market size is large enough, the contractual incompleteness effects outweighs the proximity-concentration argument, leading to a non monotonic relation between distance and foreign direct investment. Finally, the crucial assumption of firms’ heterogeneity à la Melitz (2003) allows Antras and Helpman (2004, 2008) to study the effect of productivity on the relative profitability of the four organizational forms displayed in Figure 1. They

\footnotetext{
${ }^{7}$ Put another way, in choosing between export and local production, final good producers trade-off the low governance costs, associated to the first option, with the low trade costs, implied by the second one, resembling the standard proximity-concentration argument (see, for instance, Brainard 1997): firms invest abroad when the gain from avoiding transportation costs out-weights the cost of maintaining capacity in multiple markets.

${ }^{8}$ Put another way, in choosing between integration and outsourcing, multinational firms trade-off the low cost of managing distant operations, related to the first option, with the low trade costs of arm's length trade, in a context of contractual incompleteness and double-sided hold up problem. This arises because both parties make relation-specific investments under outsourcing. Indeed, intermediate goods are fully tailored to a particular final product and the final good producer, by assumption, needs to make a relation specific investment in the assembly line.
} 
find that: in low tech sectors integration never occurs; firms with higher productivity outsource in the South, firms with lower productivity outsource in the North. In high tech sectors, one may observe any contractual arrangement: firms with higher productivity buy inputs from the South, firms with lower productivity buy inputs from the North; among firms that buy inputs from the same country, higher productivity players integrate, lower productivity players outsource.

To the best of our knowledge, applications of the G-H-M view to FDI mainly consist of theoretical contributions, due to the lack of suitable data and the intrinsic difficulty to test complex models and find good proxies for CI (Helpman 2006). Although Antras (2003), Yeaple (2006), Nunn and Trefler (2008), Corcos et al. (2008) and Tomiura (2007) provide some empirical evidence, most of them offer only an indirect test of the CI argument, because no measure of contractual incompleteness is included in the econometric estimates. Moreover, results are not conclusive, and support to the theoretical models is rather weak.

To fill this gap, in Section 3, we regress Italian firms' choice to outsource production on a measure of contractual incompleteness. At this stage, it is worth noticing that we do not aim at testing any specific model, among those reviewed above, but we rather try to capture the relationship between contractual incompleteness and the international outsourcing/FDI trade-off - if any - in the general spirit of those models. Put another way, we wonder whether CI plays any role in orienting Italian firms sourcing strategies, and whether its effect is positive (as suggested by Antras 2003); Antras and Helpman 2004; Grossman and Helpman 2003; and Ottaviano and Turrini 2007), or negative (as compatible with Antras and Helpman 2008).

Based on the above discussion, we expect CI to be a significant regressor in the international outsourcing equation. As for its sign, there is ample room for empirical investigation, given that it is still an open issue, from a theoretical point of view.

\section{Empirical Analysis}

In this Section, we explore Italian firms' choice of international outsourcing, through a large dataset at the micro level. The discussion is organized as follows: first we present the data (3.1), and then we discuss the econometric specification and the main findings 
(3.2), devoting particular attention to the matching between theoretical priors and empirical posteriors.

\subsection{Data}

For the purpose of the present research, five data sources are worth mentioning: the Capitalia Survey on Manufacturing Firms (Indagine sulle Imprese Manifatturiere), AIDA (Analisi Informatizzata Delle Aziende), Centrale dei Bilanci, Input-Output (I-O) tables and Rauch (1999).

More precisely, our dataset builds on a merge between Capitalia, AIDA and Centrale dei Bilanci, that was prepared within the research project - "International Fragmentation of Production. New Organizational Modes and the Role of Information Technologies" financed by the Italian Ministry of Education. These data are accessible only by researchers working on the above mentioned project, and they represent the core of our firm-level analysis. For the sake of clarity, in what follows, we refer to these data as the "core database", to be distinguished by the enriched version employed in the present paper.

The Capitalia survey provides micro evidence about MNEs' international business. Capitalia is one of the largest Italian banks and it periodically submits a questionnaire to client companies with more than 10 employees. The panel design is stratified and rotating. The result is a very detailed survey that covers a number of topics such as business, employment, innovation, internationalization and management. Our dataset relies on the eighth and the ninth waves, so our time span goes from 1998 to 2003. More recent data have not been included because the questionnaire changed after 2003, making new data hardly comparable with old ones.

At this stage, it should be mentioned that most of the Capitalia questions refer to the entire three-year period, rather than to each year, therefore our dataset only includes one observation for firms surveyed in one wave, and two for those surveyed in both ${ }^{9}$. This is the reason why we do not run any panel regression, but rather stick to a cross sectional

\footnotetext{
${ }^{9}$ See Table 1 for more details.
} 
analysis. When yearly data are available, the 1998 or 2001 values are included in the econometric specification ${ }^{10}$.

At the same time, we consider the entire sample, instead of looking at each wave individually, to be consistent with our measure of CI. As explained in (3.2), we cannot analyze the influence of contractual incompleteness on FDI for each individual wave, since our estimator exploits the temporal variation in the industry-level of CI, to distinguish the impact of contractual incompleteness from industry fixed effects.

To complete firm-level information, adding to those included in the Capitalia survey, some balance sheet details from AIDA and Centrale dei Bilanci are included in the core database, and they cover yearly data between 1998 and 2003.

The sample is further restricted through a trimming procedure that drops observations with extreme growth rate for value added, capital, number of white collars and number of blue collars. In the end, our dataset covers 4364 firms appearing in at least one wave, and 1424 firms appearing in both.

For the purpose of the present research, we have extended the core database to include key industry-level details. This allowed us to build a new measure of contractual incompleteness, that is consistent with the theory reviewed in Section 2, and results from a combination of Input-Output tables and Rauch (1999)'s classification of the 4-digit SITC Rev.2 industries, as described below.

\subsection{Specification and results}

According to the literature reviewed in Section 2, contractual incompleteness is a key determinant of the international outsourcing/FDI trade-off. Our basic equation is set accordingly. In particular, we move from parsimonious specifications in which, adding to the CI measure, we include only firm-level controls, to richer ones that allow for a number of robustness checks at the industry- and province-level.

Our unit of analysis is the parent company; the basic specification, defined in (1), follows a probit model, however results are robust when using a simple linear probability model or a logit specification.

\footnotetext{
${ }^{10}$ This is the reason why we adopt the 1998 and 2001 Input-Output tables to construct our CI measure, as explained in (3.2).
} 
$\operatorname{PR}\left(\right.$ OUTSOURCIN $\left.G_{i j p t}=1\right)=\Phi\left(C I_{j t} \cdot \alpha+F I R M_{-} C T R L_{i t} \beta+\varepsilon_{i t}\right)$

In what follows, we provide a brief variable description; for more details, see Table 1. Summary statistics and correlations are reported in the Appendix.

OUTSOURCING is the dependent variable, referred to firm $i$, belonging to sector $j$, located in province $p$, at time $t$. To exploit the richness of the Capitalia dataset, two alternative measures of international outsourcing are employed, called OUT and BUY. OUT is a dummy, taking value 1 if the MNE has engaged in outsourcing during the period of interest, and 0 otherwise. The pro of this variable is that it relies on a large number of observations, given that most of the surveyed enterprises answered to the related question. The con is that it is hard to interpret its 0 values. Indeed, if a firm has not engaged in outsourcing, it must either be the case that it invested directly abroad or that it never intended to internationalize. Therefore a significant effect of CI on OUT would not capture the impact of contractual incompleteness on the relative prevalence of international outsourcing over FDI, but rather on Italian firms’ propensity to externalize part of their production process, either domestically or abroad. This is the reason why we employ also $B U Y$. This dummy refers only to firms realizing part of their production process in a foreign country, and it takes value 1 if they have outsourced during the period of interest, and 0 if they have kept all production activities within the boundaries of some foreign affiliate. The pro of $B U Y$ is that it captures precisely the trade-off between international outsourcing and FDI, overcoming the limits of OUT. The con is that, to construct it, we need to intersect three distinct questions from the Capitalia survey so, due to missing values, we end up with a smaller number of observations. In light of these considerations, we prefer to keep both measures, rather than restricting attention to one of them. We believe that the resulting picture is more complete and informative and it provides a better understanding of the CI effect on firms' organizational decision ${ }^{11}$.

\footnotetext{
11 Although the theory reviewed in Section 2 considers a clear-cut trade-off between international outsourcing and FDI, from an empirical point of view, it would be interesting to allow for some degree of overlapping between these two categories. Indeed, it is likely that some multinational enterprises invest in a foreign country but, at the same time, decide to outsource part of their production process in the same or in a different country. Unfortunately, our data do not allow us to study this phenomenon. This is because of
} 
As far as the right hand side of equation (1) is concerned, $C I$ is our measure of contractual incompleteness and FIRM_CTRL is a matrix containing firm-level control regressors; $\alpha$ and $\beta$ are parametric vectors associated to the different types of independent variables and $\varepsilon$ denotes the error term.

Following closely Nunn (2007), our index of CI measures the industry-level degree of contractual incompleteness that characterizes transactions among firms belonging to a given industry and their suppliers, according to the literature reviewed in Section 2. Therefore, our proxy is set as follows.

To quantify the importance of relation-specific investments, through Input-Output tables, we first construct a variable that measures which components are used and in what proportion in the production of each final good. Instead of sticking to US I-O information, as in Nunn (2007), we employ European data, to be as close as possible to the Italian case. In particular, we consider the UK 1998 and 2001 Input-Output tables, covering 77 manufacturing industries, because they were the only ones available at an aggregation level between 2- and 3-digit NACE, by the time this paper was written ${ }^{12}$. Then, to identify which inputs require relation-specific investments, we adopt Rauch (1999)'s classification of the 1,189 4-digit SITC Rev.2 industries in three groups, based on the way products are sold: on a standardized exchange market, with a reference price, or neither of the two. The intuition is straightforward. If an input is sold on an exchange, this means that its market is thick, with many alternative buyers and sellers. As a result, the value of the input inside and outside the buyer-seller relationship is likely to be the

two reasons. First, the Capitalia survey does not provide any information regarding the host market. Therefore, we cannot distinguish sourcing strategies across different locations. Second, based on the survey results, it seems that too few Italian enterprises do both FDI and international outsourcing to build a related category in the dependent variable. For instance, if one wants to extend $B U Y$ by considering firms keeping all production activities within their boundaries and firms outsourcing at least part of their production process abroad, he/she finds that less than $0.5 \%$ of the sample falls within this case. Hence, from a statistical point of view, it makes little sense to study an overlapping between FDI and international outsourcing with the available data.

${ }^{12}$ For instance, Italian tables were available only at 2-digit level, so data were too aggregated for our purposes. Nonetheless, Ellison et al. (2010) and Mariotti et al. (2010) rigorously show that the use of another country I-O table is a good instrumenting device, because it properly deals with endogeneity issues. 
same, and the scope for hold-up is limited. If a buyer attempts to renegotiate a lower price, then the seller can simply take the input to another buyer so, by definition, there is no contractual incompleteness. If an input is not sold on a standardized exchange, it may be reference priced in trade publications, which are purchased by its potential buyers and sellers. Trade publications are produced only if there are a sufficiently large number of purchasers; therefore inputs not sold on a standardized exchange but reference priced can be thought of as having an intermediate level of market thickness and relation-specificity. Finally, inputs not sold on a standardized exchange nor reference priced are characterized by minimum level of market thickness and maximum level of relation-specificity.

In light of the literature reviewed in Section 2, we identify contractual incompleteness with relation-specificity à la Rauch (1999). Hence, CI is assumed to vary across the different types of goods, as in Antras and Helpman (2008), being minimum for those exchanged on a standardized market, medium for those having at least a reference price and maximum for those neither exchanged on a standardized market, nor having a reference price.

In order to match Rauch (1999)'s taxonomy with I-O information, we develop a new concordance between the SITC and the UK sector classification. Hence, for each of the 77 industries, we define a measure $R_{k t}$ that captures the share of goods produced in industry $j$ at time $t$ that are relation-specific, namely not sold on a standardized exchange market, nor reference priced.

At the end of this process, our index of upstream contractual intensity, with values on the zero-one interval, is set as follows:

$$
C I_{j t}=\sum_{k} \frac{u_{j k t}}{u_{j t}} R_{k t}
$$

In equation (2), $u_{j k t}$ is the value of input $k$ used in industry $j$ at time $t$, and the $u_{j t}$ the value of all inputs used in industry $j$ at time $t$. Therefore, $\frac{u_{j k t}}{u_{j t}}$ denotes the relative 
importance of every input used for production of final good $j$, based on UK I-O data, and $R_{k t}$ measures its relation specificity, based on Rauch (1999) $)^{13}$.

Given that Rauch (1999) provides both a liberal and a conservative taxonomy of the traded goods - the first maximizing and the second minimizing the number of commodities classified as either organized exchanged or reference priced - we build two alternative measures of contractual incompleteness, called CI_LIBERAL and CI_CONSERV, to be employed in the econometric analysis. At this stage, it is worth mentioning that these measures are time varying, so they can be employed in regression models including also industry fixed effects. Since results are highly consistent, when switching from one definition to the other, Table 4, in the Appendix, summarizes the output of our computations for CI_LIBERAL: columns 2 and 3 contain the values of contractual incompleteness in 1998 and 2001, while columns 4 and 5 provide a decreasing order rank of every sector in terms of $\mathrm{CI}^{14}$.

Adding to our core variables CI_LIBERAL and CI_CONSERV, a number of control regressors are also considered in equation (1), to proxy for firm-level characteristics that may play a role in orienting the international outsourcing/FDI trade-off, but over which we do not have any theoretic expectation. Matrix FIRM_CTRL includes size (EMPLOYEES), age (AGE), group affiliation (GROUP), international experience $(E X P E R I E N C E)^{15}$, the number of banks the MNE is working with (BANKS), whether the

\footnotetext{
${ }^{13}$ Employing Input-Output tables to construct our index of CI is effective to measure the industry-level degree of contractual incompleteness that characterizes transactions among firms belonging to a given industry and their suppliers. Nonetheless, we are aware of the fact that it poses some limits to the present analysis, as it treats all potential outsourcers or investors in a given industry as characterized by the same contractual incompleteness, while CI is more likely to depend on the single transaction, more than the sector. Unfortunately, data limitation prevents us from measuring CI at firm-level, which would certainly improve our empirical understanding. To partially overcome this problem, we tried several interactions between contractual incompleteness and firm-level measures of technology and innovation, but none of them turned out to be significant.

${ }^{14}$ Even if based on different I-O tables, our proxy is strongly consistent with the one provided by Nunn (2007), and results in a similar ranking across sectors. This is an important robustness check for what follows.

15 As explained in Table 1, EXPERIENCE groups some internationalization strategies under the same regressor, instead of splitting them across different variables. This is because each strategy involves just a
} 
firm is listed on the Stock Exchange (LISTED), technology indicators such as investment in Research and Development (R\&DINV), investment in Information and Communication Technologies (ICT_INV), innovation (INNOVATION), and human capital variables as the share of graduates (GRADUATES), white collars (W_COLLARS) and high skilled human capital (H_SKILLED) over total employment. A measure of total factor productivity (TFP) is also included in (1), and it is defined as follows. Along the argument of Levinsohn and Petrin (2003), the production function for a generic category $j$ can be written as in (3), where all variables are in logarithm:

$Y_{i j t}=\alpha_{i}+\beta_{1} W_{i j t}+\beta_{2} B_{i j t}+\beta_{3} K_{i j t}+\omega_{i t}+\varepsilon_{i j t}$

$Y_{i j t}$ is value added by firm $i$ in category $j$ in year $t$, deflated by the Producer Price Index for the appropriate two-digit NACE industry. $K_{i j t}$ denotes fixed assets, deflated by the simple average of the deflators for all NACE sectors, as in Smarzynska Javorcik (2004). $W_{i j t}$ indicates the number of white collars, $B_{i j t}$ the number of blue collars and $\omega_{i t}$ is the productivity component. Based on equation (3), productivity residuals are estimated under the semi-parametric approach proposed by Levinsohn and Petrin (2003), to control for simultaneity and selection problems. ${ }^{16}$

Table 1: Variables description

\begin{tabular}{|l|l|}
\hline Variable & Description \\
\hline OUT & $\begin{array}{l}\text { Dummy variable, } 1 \text { if the firm has engaged in outsourcing, 0 otherwise. } \\
\text { Type: regressand. } \\
\text { Source: Capitalia Survey on Manufacturing Firms ( } 8^{\text {th }} \text { and } 9^{\text {th }} \text { wave). Authors' elaboration from question E8 (Has the firm } \\
\text { outsourced production during the period } 2001-2003 ?)^{17} .\end{array}$ \\
\hline BUY & $\begin{array}{l}\text { Dummy variable, } 1 \text { if the firm has realized part of its production process in a foreign country through outsourcing, and } 0 \text { if } \\
\text { the firm has realized part of its production process in a foreign country within the boundaries of a foreign affiliate. } \\
\text { Type: regressand. } \\
\text { Source: Capitalia Survey on Manufacturing Firms (8 } \\
\text { realized part of its production process in a foreign country during the period } 2001-2003 ?) \text {, E8 (Has the firm outsourced }\end{array}$ \\
\hline
\end{tabular}

minority of Italian enterprises. However, results are consistent when considering each strategy in a separate dummy.

${ }^{16}$ See also Olley and Pakes (1996).

${ }^{17}$ Questions from the Capitalia survey are displayed as in the $9^{\text {th }}$ wave, but the same items appear in the $8^{\text {th }}$ wave questionnaire. 


\begin{tabular}{|c|c|}
\hline & oduction during the perio \\
\hline CI_LIBERAL & $\begin{array}{l}\text { Measure of contractual incompleteness at the industry (2-3 digit NACE) level. } \\
\text { Type: industry-level core regressor. } \\
\text { Source: Authors' elaborations from UK Input-Output tables and Rauch (1999)'s liberal classification of manufacturing } \\
\text { sectors. }\end{array}$ \\
\hline CI_CONSERV & $\begin{array}{l}\text { Measure of contractual incompleteness at the industry (2-3 digit NACE) level. } \\
\text { Type: industry-level core regressor. } \\
\text { Source: Authors' elaborations from UK Input-Output tables and Rauch (1999)'s conservative classification of manufacturing } \\
\text { sectors. }\end{array}$ \\
\hline EMPLOYEES & $\begin{array}{l}\text { Number of employees of the parent firm (thousands of units). } \\
\text { Type: firm-level control regressor. } \\
\text { Source: Capitalia Survey on Manufacturing Firms ( } 8^{\text {th }} \text { and } 9^{\text {th }} \text { wave). Authors' elaboration from question B1.1.6 (Total } \\
\text { number of employees in 2001, 2002, 2003). }\end{array}$ \\
\hline TFP & $\begin{array}{l}\text { Natural logarithm of total factor productivity (Levinsohn-Petrin estimate). } \\
\text { Type: firm-level control regressor. } \\
\text { Source: Authors’ elaborations from AIDA and Centrale dei Bilanci. }\end{array}$ \\
\hline$\overline{A G E}$ & $\begin{array}{l}\text { Natural logarithm of firm's age, defined as the difference between } 2003 \text { and the year of firm's establishment. } \\
\text { Type: firm-level control regressor. } \\
\text { Source: personal elaborations from ISTAT data. }\end{array}$ \\
\hline GROUP & $\begin{array}{l}\text { Dummy variable, } 1 \text { if the parent firm belongs to a business group, } 0 \text { otherwise. } \\
\text { Type: firm-level control regressor. } \\
\text { Source: Capitalia Survey on Manufacturing Firms ( } 8^{\text {th }} \text { and } 9^{\text {th }} \text { wave). Authors' elaboration from question A8.1 (Does the firm } \\
\text { belong to a business group?). }\end{array}$ \\
\hline EXPERIENCE & $\begin{array}{l}\text { Dummy variable, } 1 \text { if the firm has been engaged in foreign penetration operations, commercial or production partnerships } \\
\text { abroad, } 0 \text { otherwise. } \\
\text { Type: firm-level control regressor. } \\
\text { Source: Capitalia Survey on Manufacturing Firms ( }{ }^{\text {th }} \text { and } 9^{\text {th }} \text { wave). Authors' elaboration from questions D2.1.1 (Has the } \\
\text { firm been engaged in foreign penetration operations in the period 2001-2003?), D2.2 (Has the firm been engaged in } \\
\text { commercial partnerships in the period 2001-2003?), and D2.5 (Has the firm been engaged in production partnerships in the } \\
\text { period 2001-2003?). }\end{array}$ \\
\hline BANKS & $\begin{array}{l}\text { Number of banks with which the firm was working at the end of } 2003 . \\
\text { Type: firm-level control regressor. } \\
\text { Source: Capitalia Survey on Manufacturing Firms ( }{ }^{\text {th }} \text { and } 9^{\text {th }} \text { wave). Authors' elaboration from question F1.1 (How many } \\
\text { banks was the firm working with at the end of 2003?). }\end{array}$ \\
\hline LISTED & $\begin{array}{l}\text { Dummy variable, } 1 \text { if the firm is listed on the Stock Exchange, } 0 \text { otherwise. } \\
\text { Type: firm-level control regressor. } \\
\text { Source: Capitalia Survey on Manufacturing Firms ( } 8^{\text {th }} \text { and } 9^{\text {th }} \text { wave). Authors' elaboration from question F2.6.1 (Is the firm } \\
\text { listed on the Stock Exchange?). }\end{array}$ \\
\hline GRADUATES & $\begin{array}{l}\text { Percentage of employees holding a degree over total firm's employment. } \\
\text { Type: firm-level control regressor; it is an indicator of the parent firm's human capital. } \\
\text { Source: Capitalia Survey on Manufacturing Firms ( } 8^{\text {th }} \text { and } 9^{\text {th }} \text { wave). Authors' elaboration from questions B1.1.6 (Total } \\
\text { number of employees in 2001, 2002, 2003) and B1.2.3 (Number of employees holding a degree in 2001, 2002, 2003). }\end{array}$ \\
\hline W_COLLARS & $\begin{array}{l}\text { Percentage of white collars over total firm's employment. } \\
\text { Type: firm-level control regressor; it is an indicator of the parent firm's human capital. } \\
\text { Source: Capitalia Survey on Manufacturing Firms ( } 8^{\text {th }} \text { and } 9^{\text {th }} \text { wave). Authors' elaboration from questions B1.1.6 (Total } \\
\text { number of employees in 2001, 2002, 2003) and B1.1.3 (Number of white collars in 2001, 2002, 2003). }\end{array}$ \\
\hline
\end{tabular}




\begin{tabular}{|c|c|}
\hline H_SKILLED & $\begin{array}{l}\text { Percentage of employees engaged in R\&D activity over total firm's employment. } \\
\text { Type: firm-level control regressor; it is a proxy for the parent firm's human capital. } \\
\text { Source: Capitalia Survey on Manufacturing Firms ( } 8^{\text {th }} \text { and } 9^{\text {th }} \text { wave). Authors' elaboration from questions B1.1.6 (Total } \\
\text { number of employees in 2001, 2002, 2003) and B4.1 (Number of employees engaged in R\&D activities in 2001, 2002, 2003). }\end{array}$ \\
\hline$R \& D \_I N V$ & $\begin{array}{l}\text { Dummy variable, } 1 \text { if the firm has invested in R\&D, } 0 \text { otherwise. } \\
\text { Type: firm-level control regressor; it is a proxy for the parent firm's technological endowment. } \\
\text { Source: Capitalia Survey on Manufacturing Firms ( } 8^{\text {th }} \text { and } 9^{\text {th }} \text { wave). Authors' elaboration from question C2.2.1 (Has the } \\
\text { firm invested in R\&D during the period } 2001-2003 \text { ?). }\end{array}$ \\
\hline$I C T \_I N V$ & $\begin{array}{l}\text { Dummy variable, } 1 \text { if the firm has invested in Information and Communication Technologies, } 0 \text { otherwise. } \\
\text { Type: firm-level control regressor; it is a proxy for the parent firm's technological endowment. } \\
\text { Source: Capitalia Survey on Manufacturing Firms ( } 8^{\text {th }} \text { and } 9^{\text {th }} \text { wave). Authors' elaboration from question C1.3.1 (Has the } \\
\text { firm invested in hardware, software or Information and Communication Technologies in the period 2001-2003?). }\end{array}$ \\
\hline INNOVATION & $\begin{array}{l}\text { Dummy variable, } 1 \text { if the firm has introduced any product or process innovation, } 0 \text { otherwise. } \\
\text { Type: firm-level control regressor; it is a proxy for the parent firm's technological endowment. } \\
\text { Source: Capitalia Survey on Manufacturing Firms ( } 8^{\text {th }} \text { and } 9^{\text {th }} \text { wave). Authors' elaboration from question C2.1.1 (Has the } \\
\text { firm introduced any product or process innovation in the period } 2001-2003 \text { ?). }\end{array}$ \\
\hline
\end{tabular}

Estimates from the basic specification are shown in the left panel of Table 2, where the dependent variable is $O U T$, and Table 3, where the dependent variable is $B U Y$. Contractual incompleteness is measured according to the liberal definition of Nunn (2007). Results with the conservative measure - which are completely consistent with those reported in the main text - are reported in the Appendix.

From Tables 2 and 3 we see that contractual incompleteness is a relevant driver of firms' outsourcing decision. According to Antras and Helpman (2008), a decrease in contractibility - i.e. an increase in CI - may either encourage or discourage externalization of production activities. Unfortunately, our data do not allow us to distinguish between the two theoretical cases in which a change in contractual incompleteness refers to the input controlled by the input supplier or the final good producer. However, empirical results from the Capitalia data are cleat-cut and robust to different specifications. In fact, an inspection of columns 1-6 of Tables 1 and 2 suggests that CI has a positive and significant impact on $O U T$, meaning that an increase in relation-specificity favours outsourcing of Italian enterprises.

In addition to CILLIBERAL, our estimates reveal that firms' $A G E$, number of EMPLOYEES, and EXPERIENCE in managing foreign operations have a positive and significant effect on the $O U T$ choice. Put another way, the larger, the older and the more international oriented the players, the more likely the outsourcing solution. Technological 
indicators are positive and significant as well, while human capital variables do not seem to play any sizeable role in equation $(1)^{18}$. As far as the MNEs' productivity is concerned, our TFP measure, although significant only in the basic specification, exhibits a negative sign, consistently with the theoretical models reviewed in Section 2. Indeed, when heterogeneity in productivity is assumed (see, for instance: Antras and Helpman 2004, 2008), among firms that buy inputs from the same country, higher productivity players integrate, lower productivity players outsource. Results are consistent when moving from $O U T$ to $B U Y$ as a dependent variable.

Our basic equation is then completed by industry $\left(\eta_{j}\right)$ and province $\left(\eta_{p}\right)$ fixed effects, to see whether contractual incompleteness is still significant after controlling for firms' NACE 3 digits sector, and geographical location ${ }^{19}$.

The estimated equation is as follows:

$\operatorname{PR}\left(\right.$ OUTSOURCIN $\left.G_{i j p t}=1\right)=\Phi\left(C I_{J T} \cdot \alpha+F I R M_{-} C T R L_{i t} \cdot \beta+\eta_{J T} \cdot \gamma+\eta_{P T} \sigma+\varepsilon_{i t}\right)$

Unfortunately the Capitalia survey does not provide any information about the host market; therefore no country variable is included in the econometric analysis, as a further robustness check $^{20}$.

\footnotetext{
${ }^{18}$ To extend the empirical analysis and better capture the relationship between contractual incompleteness and international outsourcing, we allowed for several interactions between CI and firm-level variables. This is because, in principle, the effect of contractual incompleteness may differ for firm size, technology or human capital. However, our results (not shown) suggest the opposite. Indeed, CI-LIBERAL and CI_CONSERV - namely the non interacted indicators of CI - remain significant when including the interacted terms, but the interacted terms are never significant. More information is available from authors upon request.

${ }^{19}$ For the sake of completeness, we stick to a rather rich classification of industries - measured with dummies covering all NACE 3 digits sectors - and geographical location - measured with dummies covering all Italian provinces. We believe it is an effective controlling device to check the robustness of our results, better than considering macro categories for industry and space. However, to make Tables 2, 3, 7 and 8 readable, we cannot display coefficients related to industry and location, because too many dummies should be shown. For this reason, these tables simply report whether industry and province fixed effects are included or not. More information is available from authors upon request.

${ }^{20}$ For the same reason, we cannot build any country-level proxy for contractual incompleteness, such as the quality of the legal system, considered elsewhere (see, for instance, Nunn 2007). One may argue that this
} 
Probit estimates of equation (4) are shown in the right panel of Tables 2 and 3.

Results are strongly consistent with those reported above for the basic specification, meaning that contractual incompleteness plays a positive and significant role in orienting both absolute and relative outsourcing of Italian enterprises.

lack of information on the host country compromises the robustness of the empirical model and its results. However, as shown elsewhere (see, for instance: Castellani 2007; De Benedictis and Giovannetti 2008) Italian enterprises are quite open, and their internationalization trajectories spread worldwide. Hence, we are quite confident that multinational enterprises included in our sample are characterized by a reasonable variety in terms of foreign location, even though we cannot control for this. 
Table 2: Probit estimates of equations 1 (left) and 4 (right), with dependent variable OUT, liberal definition of contractual incompleteness ${ }^{21}$

\begin{tabular}{|c|c|c|c|c|c|c|c|c|c|c|c|c|}
\hline & \multicolumn{6}{|c|}{ basic specification } & \multicolumn{6}{|c|}{ robustness check } \\
\hline & $\begin{array}{c}\text { OUT } \\
(1) \\
\end{array}$ & $\begin{array}{l}\text { OUT } \\
(2) \\
\end{array}$ & $\begin{array}{l}\text { OUT } \\
(3) \\
\end{array}$ & $\begin{array}{l}\text { OUT } \\
(4) \\
\end{array}$ & $\begin{array}{c}\text { OUT } \\
(5) \\
\end{array}$ & $\begin{array}{c}\text { OUT } \\
(6)\end{array}$ & $\begin{array}{c}\text { OUT } \\
(7) \\
\end{array}$ & $\begin{array}{c}\text { OUT } \\
(8)\end{array}$ & $\begin{array}{c}\text { OUT } \\
(9) \\
\end{array}$ & $\begin{array}{l}\text { OUT } \\
(10)\end{array}$ & $\begin{array}{l}\text { OUT } \\
(11)\end{array}$ & $\begin{array}{l}\text { OUT } \\
(12) \\
\end{array}$ \\
\hline CI_LIBERAL & $\begin{array}{c}0.185 \\
(0.000)^{\star \star \star}\end{array}$ & $\begin{array}{c}0.173 \\
(0.000)^{\star \star \star}\end{array}$ & $\begin{array}{c}0.173 \\
(0.000)^{\star \star \star}\end{array}$ & $\begin{array}{c}0.179 \\
(0.000)^{\star \star \star}\end{array}$ & $\begin{array}{c}0.178 \\
(0.000)^{\star \star \star}\end{array}$ & $\begin{array}{c}0.172 \\
(0.000)^{\star \star \star}\end{array}$ & $\begin{array}{c}0.130 \\
(0.062)^{\star}\end{array}$ & $\begin{array}{c}0.122 \\
(0.081)^{\star}\end{array}$ & $\begin{array}{c}0.134 \\
(0.080)^{\star}\end{array}$ & $\begin{array}{c}0.118 \\
(0.092)^{\star}\end{array}$ & $\begin{array}{c}0.132 \\
(0.072)^{\star}\end{array}$ & $\begin{array}{c}0.144 \\
(0.076)^{\star}\end{array}$ \\
\hline TFP & $\begin{array}{c}-0.019 \\
(0.061)^{\star}\end{array}$ & $\begin{array}{c}-0.021 \\
(0.040)^{\star \star}\end{array}$ & $\begin{array}{l}-0.017 \\
(0.123)\end{array}$ & $\begin{array}{c}-0.019 \\
(0.055)^{\star}\end{array}$ & $\begin{array}{c}-0.021 \\
(0.063)^{\star}\end{array}$ & $\begin{array}{l}-0.017 \\
(0.168)\end{array}$ & $\begin{array}{l}-0.011 \\
(0.484)\end{array}$ & $\begin{array}{l}-0.012 \\
(0.445)\end{array}$ & $\begin{array}{l}-0.004 \\
(0.790)\end{array}$ & $\begin{array}{l}-0.010 \\
(0.498)\end{array}$ & $\begin{array}{l}-0.020 \\
(0.243)\end{array}$ & $\begin{array}{l}-0.014 \\
(0.467)\end{array}$ \\
\hline GROUP & $\begin{array}{c}0.021 \\
(0.205)\end{array}$ & $\begin{array}{c}0.018 \\
(0.267)\end{array}$ & $\begin{array}{l}0.015 \\
(0.394)\end{array}$ & $\begin{array}{c}0.019 \\
(0.234)\end{array}$ & $\begin{array}{c}0.026 \\
(0.151)\end{array}$ & $\begin{array}{c}0.016 \\
(0.413)\end{array}$ & $\begin{array}{c}0.020 \\
(0.243)\end{array}$ & $\begin{array}{c}0.018 \\
(0.303)\end{array}$ & $\begin{array}{c}0.012 \\
(0.508)\end{array}$ & $\begin{array}{c}0.018 \\
(0.293)\end{array}$ & $\begin{array}{c}0.023 \\
(0.201)\end{array}$ & $\begin{array}{c}0.013 \\
(0.517)\end{array}$ \\
\hline$A G E$ & $\begin{array}{c}0.018 \\
(0.091)^{\star}\end{array}$ & $\begin{array}{c}0.017 \\
(0.111)\end{array}$ & $\begin{array}{c}0.018 \\
(0.131)\end{array}$ & $\begin{array}{c}0.019 \\
(0.079)^{\star}\end{array}$ & $\begin{array}{c}0.029 \\
(0.012)^{\star \star}\end{array}$ & $\begin{array}{c}0.025 \\
(0.048)^{\star \star}\end{array}$ & $\begin{array}{c}0.013 \\
(0.231)\end{array}$ & $\begin{array}{c}0.013 \\
(0.255)\end{array}$ & $\begin{array}{l}0.014 \\
(0.241)\end{array}$ & $\begin{array}{c}0.015 \\
(0.187)\end{array}$ & $\begin{array}{c}0.025 \\
(0.043)^{\star \star}\end{array}$ & $\begin{array}{c}0.022 \\
(0.104)\end{array}$ \\
\hline EMPLOYEES & $\begin{array}{c}0.055 \\
(0.003)^{\star \star \star}\end{array}$ & $\begin{array}{c}0.051 \\
(0.004)^{\star \star \star}\end{array}$ & $\begin{array}{c}0.051 \\
(0.005)^{\star \star \star}\end{array}$ & $\begin{array}{c}0.056 \\
(0.002)^{\star \star \star}\end{array}$ & $\begin{array}{c}0.027 \\
(0.023)^{\star \star}\end{array}$ & $\begin{array}{c}0.024 \\
(0.286)\end{array}$ & $\begin{array}{c}0.045 \\
(0.015)^{\star \star}\end{array}$ & $\begin{array}{c}0.043 \\
(0.020)^{\star \star}\end{array}$ & $\begin{array}{c}0.041 \\
(0.032)^{\star \star}\end{array}$ & $\begin{array}{c}0.046 \\
(0.014)^{\star \star}\end{array}$ & $\begin{array}{c}0.014 \\
(0.513)\end{array}$ & $\begin{array}{c}0.009 \\
(0.681)\end{array}$ \\
\hline EXPERIENCE & $\begin{array}{c}0.074 \\
(0.000)^{\star \star \star}\end{array}$ & $\begin{array}{c}0.064 \\
(0.000)^{\star \star \star}\end{array}$ & $\begin{array}{c}0.057 \\
(0.001)^{\star \star \star}\end{array}$ & $\begin{array}{c}0.063 \\
(0.000)^{\star \star \star}\end{array}$ & $\begin{array}{c}0.064 \\
(0.000)^{\star \star \star}\end{array}$ & $\begin{array}{c}0.048 \\
(0.006)^{\star \star \star}\end{array}$ & $\begin{array}{c}0.077 \\
(0.000)^{\star \star \star}\end{array}$ & $\begin{array}{c}0.069 \\
(0.000)^{\star \star \star}\end{array}$ & $\begin{array}{c}0.061 \\
(0.000)^{\star \star \star}\end{array}$ & $\begin{array}{c}0.073 \\
(0.000)^{\star \star \star}\end{array}$ & $\begin{array}{c}0.070 \\
(0.000)^{\star \star \star}\end{array}$ & $\begin{array}{c}0.055 \\
(0.003)^{\star \star \star}\end{array}$ \\
\hline BANKS & $\begin{array}{c}0.005 \\
(0.026)^{\star \star}\end{array}$ & $\begin{array}{c}0.004 \\
(0.054)^{\star}\end{array}$ & $\begin{array}{c}0.003 \\
(0.203)\end{array}$ & $\begin{array}{c}0.005 \\
(0.026)^{\star \star}\end{array}$ & $\begin{array}{c}0.004 \\
(0.063)^{\star}\end{array}$ & & $\begin{array}{c}0.004 \\
(0.051)^{\star}\end{array}$ & $\begin{array}{c}0.004 \\
(0.092)^{\star}\end{array}$ & $\begin{array}{c}0.002 \\
(0.297)\end{array}$ & $\begin{array}{c}0.004 \\
(0.047)^{\star \star}\end{array}$ & $\begin{array}{c}0.004 \\
(0.071)^{\star}\end{array}$ & \\
\hline LISTED & $\begin{array}{l}-0.030 \\
(0.616)\end{array}$ & $\begin{array}{l}-0.031 \\
(0.612)\end{array}$ & $\begin{array}{l}-0.014 \\
(0.823)\end{array}$ & $\begin{array}{l}-0.050 \\
(0.419)\end{array}$ & $\begin{array}{l}-0.087 \\
(0.194)\end{array}$ & & $\begin{array}{l}-0.019 \\
(0.756)\end{array}$ & $\begin{array}{l}-0.018 \\
(0.761)\end{array}$ & $\begin{array}{l}-0.001 \\
(0.998)\end{array}$ & $\begin{array}{l}-0.037 \\
(0.545)\end{array}$ & $\begin{array}{l}-0.061 \\
(0.369)\end{array}$ & \\
\hline$R \& D \_I N V$ & & $\begin{array}{c}0.036 \\
(0.020)^{\star \star}\end{array}$ & $\begin{array}{c}0.006 \\
(0.020)^{\star \star}\end{array}$ & & & $\begin{array}{c}0.012 \\
(0.540)\end{array}$ & & $\begin{array}{c}0.031 \\
(0.058)^{\star}\end{array}$ & $\begin{array}{c}0.004 \\
(0.832)\end{array}$ & & & $\begin{array}{c}0.012 \\
(0.549)\end{array}$ \\
\hline INNOVATION & & & $\begin{array}{c}0.055 \\
(0.003)^{\star \star \star}\end{array}$ & & & $\begin{array}{c}0.060 \\
(0.002)^{\star \star \star}\end{array}$ & & & $\begin{array}{c}0.057 \\
(0.002)^{\star \star \star}\end{array}$ & & & $\begin{array}{c}0.063 \\
(0.002)^{\star \star \star}\end{array}$ \\
\hline$I C T \_I N V$ & & & $\begin{array}{c}0.047 \\
(0.016)^{\star \star}\end{array}$ & & & $\begin{array}{c}0.055 \\
(0.007)^{\star \star}\end{array}$ & & & $\begin{array}{c}0.040 \\
(0.051)^{\star}\end{array}$ & & & $\begin{array}{c}0.050 \\
(0.024)^{\star \star}\end{array}$ \\
\hline H_SKILLED & & & & $\begin{array}{c}0.121 \\
(0.193)\end{array}$ & $\begin{array}{c}0.112 \\
(0.249)\end{array}$ & $\begin{array}{l}-0.084 \\
(0.508)\end{array}$ & & & & $\begin{array}{c}0.067 \\
(0.486)\end{array}$ & $\begin{array}{c}0.046 \\
(0.652)\end{array}$ & $\begin{array}{l}-0.165 \\
(0.216)\end{array}$ \\
\hline W_COLLARS & & & & & $\begin{array}{c}0.004 \\
(0.986)\end{array}$ & $\begin{array}{c}0.008 \\
(0.997)\end{array}$ & & & & & $\begin{array}{c}0.067 \\
(0.777)\end{array}$ & $\begin{array}{c}0.084 \\
(0.744)\end{array}$ \\
\hline GRADUATES & & & & & $\begin{array}{l}-0.074 \\
(0.514)\end{array}$ & $\begin{array}{l}-0.100 \\
(0.430)\end{array}$ & & & & & $\begin{array}{l}-0.055 \\
(0.650)\end{array}$ & $\begin{array}{l}-0.075 \\
(0.586)\end{array}$ \\
\hline INDUSTRY & no & no & no & no & no & no & yes & yes & yes & yes & yes & yes \\
\hline PROVINCE & no & no & no & no & no & no & yes & yes & yes & yes & yes & yes \\
\hline Obs. & 3090 & 3089 & 2650 & 3059 & 2746 & 2358 & 3024 & 3023 & 2594 & 2995 & 2658 & 2278 \\
\hline P-value & $0.000^{\star \star \star}$ & $0.000^{\star \star \star}$ & $0.000^{\star \star \star}$ & $0.000^{\star \star \star}$ & $0.000^{\star \star \star}$ & $0.000^{\star \star \star}$ & $0.000^{\star \star \star}$ & $0.000^{\star \star \star}$ & $0.000^{\star \star \star}$ & $0.000^{\star \star \star}$ & $0.003^{\star \star \star}$ & $0.008^{\star \star \star}$ \\
\hline Pseudo R2 & 0.029 & 0.030 & 0.034 & 0.029 & 0.025 & 0.031 & 0.063 & 0.064 & 0.069 & 0.064 & 0.061 & 0.068 \\
\hline
\end{tabular}

$21 *$ means significant at $10 \%, * *$ significant at $5 \%, * * *$ significant at $1 \%$. Marginal effects and p-values (in parenthesis) are shown. Standard errors are clustered at the industry level. Pseudo $\mathrm{R}^{2}$ is a typical measure for goodness of fit in discrete-dependent-variable models. The expression for Pseudo $\mathrm{R}^{2}$ is $1-1 /\left[1+2\left(\log L_{1^{-}}\right.\right.$ $\left.\left.\log L_{0}\right) / N\right]$, where $N$ is the total number of observations, $L_{1}$ is the maximum log-likelihood value of the model of interest, and $L_{0}$ the maximum value of the log-likelihood function when all the parameters, except the intercept, are set equal to 0 . P-value denotes the P-value of the joint null-hypothesis. 
Table 3: Probit estimates of equations 1 (left) and 4 (right), with dependent variable BUY, liberal definition of contractual incompleteness ${ }^{15}$

\begin{tabular}{|c|c|c|c|c|c|c|c|c|c|c|c|c|}
\hline & \multicolumn{6}{|c|}{ basic specification } & \multicolumn{6}{|c|}{ robustness check } \\
\hline & $\begin{array}{c}B U Y \\
(1) \\
\end{array}$ & $\begin{array}{c}B U Y \\
(2) \\
\end{array}$ & $\begin{array}{c}B U Y \\
(3) \\
\end{array}$ & $\begin{array}{c}B U Y \\
(4) \\
\end{array}$ & $\begin{array}{c}B U Y \\
(5) \\
\end{array}$ & $\begin{array}{c}B U Y \\
(6) \\
\end{array}$ & $\begin{array}{c}B U Y \\
(7) \\
\end{array}$ & $\begin{array}{c}B U Y \\
(8) \\
\end{array}$ & $\begin{array}{c}B U Y \\
(9) \\
\end{array}$ & $\begin{array}{r}B U Y \\
(10) \\
\end{array}$ & $\begin{array}{r}B U Y \\
(11) \\
\end{array}$ & $\begin{array}{r}B U Y \\
(12) \\
\end{array}$ \\
\hline CI_LIBERAL & $\begin{array}{c}0.125 \\
(0.058)^{\star}\end{array}$ & $\begin{array}{c}0.141 \\
(0.032)^{\star \star}\end{array}$ & $\begin{array}{c}0.150 \\
(0.035)^{\star \star}\end{array}$ & $\begin{array}{c}0.132 \\
(0.045)^{\star \star}\end{array}$ & $\begin{array}{c}0.127 \\
(0.073)^{\star}\end{array}$ & $\begin{array}{c}0.145 \\
(0.057)^{\star}\end{array}$ & $\begin{array}{c}0.244 \\
(0.028)^{\star \star}\end{array}$ & $\begin{array}{c}0.266 \\
(0.036)^{\star \star}\end{array}$ & $\begin{array}{c}0.279 \\
(0.086)^{\star}\end{array}$ & $\begin{array}{c}0.177 \\
(0.094)^{\star}\end{array}$ & $\begin{array}{c}0.209 \\
(0.058)^{\star}\end{array}$ & $\begin{array}{c}0.239 \\
(0.076)^{\star}\end{array}$ \\
\hline TFP & $\begin{array}{l}-0.002 \\
(0.885)\end{array}$ & $\begin{array}{l}-0.005 \\
(0.778)\end{array}$ & $\begin{array}{l}-0.009 \\
(0.592)\end{array}$ & $\begin{array}{l}-0.001 \\
(0.928)\end{array}$ & $\begin{array}{l}-0.007 \\
(0.708)\end{array}$ & $\begin{array}{l}-0.012 \\
(0.521)\end{array}$ & $\begin{array}{l}-0.011 \\
(0.805)\end{array}$ & $\begin{array}{l}-0.003 \\
(0.940)\end{array}$ & $\begin{array}{l}-0.016 \\
(0.717)\end{array}$ & $\begin{array}{l}-0.015 \\
(0.729)\end{array}$ & $\begin{array}{l}-0.005 \\
(0.911)\end{array}$ & $\begin{array}{l}-0.016 \\
(0.759)\end{array}$ \\
\hline GROUP & $\begin{array}{c}-0.082 \\
(0.003)^{\star \star \star}\end{array}$ & $\begin{array}{c}-0.075 \\
(0.006)^{\star \star \star}\end{array}$ & $\begin{array}{c}-0.073 \\
(0.013)^{\star \star}\end{array}$ & $\begin{array}{c}-0.080 \\
(0.004)^{\star \star \star}\end{array}$ & $\begin{array}{c}-0.073 \\
(0.016)^{\star \star}\end{array}$ & $\begin{array}{c}-0.066 \\
(0.041)^{\star \star}\end{array}$ & $\begin{array}{c}-0.151 \\
(0.001)^{\star \star \star}\end{array}$ & $\begin{array}{c}-0.141 \\
(0.001)^{\star \star \star}\end{array}$ & $\begin{array}{c}-0.144 \\
(0.003)^{\star \star \star}\end{array}$ & $\begin{array}{c}-0.148 \\
(0.001)^{\star \star \star}\end{array}$ & $\begin{array}{c}-0.116 \\
(0.017)^{\star \star}\end{array}$ & $\begin{array}{c}-0.111 \\
(0.036)^{\star \star}\end{array}$ \\
\hline$A G E$ & $\begin{array}{l}-0.004 \\
(0.836)\end{array}$ & $\begin{array}{l}-0.001 \\
(0.938)\end{array}$ & $\begin{array}{l}-0.007 \\
(0.703)\end{array}$ & $\begin{array}{l}-0.008 \\
(0.637)\end{array}$ & $\begin{array}{l}-0.002 \\
(0.922)\end{array}$ & $\begin{array}{l}-0.014 \\
(0.514)\end{array}$ & $\begin{array}{l}-0.006 \\
(0.823)\end{array}$ & $\begin{array}{l}-0.009 \\
(0.729)\end{array}$ & $\begin{array}{l}-0.023 \\
(0.408)\end{array}$ & $\begin{array}{l}-0.001 \\
(0.960)\end{array}$ & $\begin{array}{l}-0.006 \\
(0.830)\end{array}$ & $\begin{array}{l}-0.028 \\
(0.361)\end{array}$ \\
\hline EMPLOYEES & $\begin{array}{l}-0.023 \\
(0.418)\end{array}$ & $\begin{array}{l}-0.025 \\
(0.376)\end{array}$ & $\begin{array}{l}-0.020 \\
(0.505)\end{array}$ & $\begin{array}{l}-0.023 \\
(0.410)\end{array}$ & $\begin{array}{l}-0.004 \\
(0.913)\end{array}$ & $\begin{array}{l}-0.005 \\
(0.875)\end{array}$ & $\begin{array}{l}-0.020 \\
(0.642)\end{array}$ & $\begin{array}{l}-0.012 \\
(0.770)\end{array}$ & $\begin{array}{l}-0.004 \\
(0.933)\end{array}$ & $\begin{array}{l}-0.018 \\
(0.666)\end{array}$ & $\begin{array}{l}-0.008 \\
(0.864)\end{array}$ & $\begin{array}{l}-0.009 \\
(0.859)\end{array}$ \\
\hline EXPERIENCE & $\begin{array}{c}-0.115 \\
(0.000)^{\star \star \star}\end{array}$ & $\begin{array}{c}-0.098 \\
(0.000)^{\star \star \star}\end{array}$ & $\begin{array}{c}-0.099 \\
(0.001)^{\star \star \star}\end{array}$ & $\begin{array}{c}-0.110 \\
(0.000)^{\star \star \star}\end{array}$ & $\begin{array}{c}-0.116 \\
(0.000)^{\star \star \star}\end{array}$ & $\begin{array}{c}-0.108 \\
(0.001)^{\star \star \star}\end{array}$ & $\begin{array}{c}-0.146 \\
(0.000)^{\star \star \star}\end{array}$ & $\begin{array}{c}-0.111 \\
(0.006)^{\star \star \star}\end{array}$ & $\begin{array}{c}-0.113 \\
(0.010)^{\star \star \star}\end{array}$ & $\begin{array}{c}-0.137 \\
(0.001)^{\star \star \star}\end{array}$ & $\begin{array}{c}-0.135 \\
(0.002)^{\star \star \star}\end{array}$ & $\begin{array}{c}-0.116 \\
(0.014)^{\star \star}\end{array}$ \\
\hline BANKS & $\begin{array}{c}-0.010 \\
(0.001)^{\star \star \star}\end{array}$ & $\begin{array}{c}-0.009 \\
(0.001)^{\star \star \star}\end{array}$ & $\begin{array}{c}-0.009 \\
(0.002)^{\star \star \star}\end{array}$ & $\begin{array}{c}-0.009 \\
(0.001)^{\star \star \star}\end{array}$ & $\begin{array}{c}-0.009 \\
(0.003)^{\star \star \star}\end{array}$ & $\begin{array}{c}-0.008 \\
(0.007)^{\star \star \star}\end{array}$ & $\begin{array}{c}-0.014 \\
(0.001)^{\star \star \star}\end{array}$ & $\begin{array}{c}-0.013 \\
(0.002)^{\star \star \star}\end{array}$ & $\begin{array}{c}-0.014 \\
(0.002)^{\star \star \star}\end{array}$ & $\begin{array}{c}-0.012 \\
(0.003)^{\star \star \star}\end{array}$ & $\begin{array}{c}-0.012 \\
(0.006)^{\star \star \star}\end{array}$ & $\begin{array}{c}-0.012 \\
(0.008)^{\star \star \star \star}\end{array}$ \\
\hline LISTED & $\begin{array}{c}0.005 \\
(0.952)\end{array}$ & $\begin{array}{c}0.005 \\
(0.951)\end{array}$ & $\begin{array}{c}0.016 \\
(0.854)\end{array}$ & $\begin{array}{c}0.005 \\
(0.951)\end{array}$ & $\begin{array}{c}0.034 \\
(0.701)\end{array}$ & $\begin{array}{c}0.029 \\
(0.763)\end{array}$ & $\begin{array}{c}0.131 \\
(0.335)\end{array}$ & $\begin{array}{c}0.115 \\
(0.388)\end{array}$ & $\begin{array}{c}0.175 \\
(0.230)\end{array}$ & $\begin{array}{c}0.120 \\
(0.366)\end{array}$ & $\begin{array}{c}0.102 \\
(0.465)\end{array}$ & $\begin{array}{c}0.143 \\
(0.316)\end{array}$ \\
\hline$R \& D \_I N V$ & & $\begin{array}{c}-0.057 \\
(0.032)^{\star \star}\end{array}$ & $\begin{array}{c}-0.068 \\
(0.024)^{\star \star}\end{array}$ & & & $\begin{array}{l}-0.044 \\
(0.192)\end{array}$ & & $\begin{array}{c}-0.093 \\
(0.029)^{\star \star}\end{array}$ & $\begin{array}{c}-0.108 \\
(0.022)^{\star \star}\end{array}$ & & & $\begin{array}{l}-0.071 \\
(0.187)\end{array}$ \\
\hline INNOVATION & & & $\begin{array}{c}0.056 \\
(0.153)\end{array}$ & & & $\begin{array}{c}0.067 \\
(0.114)\end{array}$ & & & $\begin{array}{c}0.110 \\
(0.083)^{\star}\end{array}$ & & & $\begin{array}{c}0.146 \\
(0.051)^{\star}\end{array}$ \\
\hline ICT_INV & & & $\begin{array}{c}-0.054 \\
(0.099)^{\star}\end{array}$ & & & $\begin{array}{l}-0.047 \\
(0.284)\end{array}$ & & & $\begin{array}{l}-0.026 \\
(0.741)\end{array}$ & & & $\begin{array}{l}-0.058 \\
(0.531)\end{array}$ \\
\hline H_SKILLED & & & & $\begin{array}{c}-0.184 \\
(0.098)^{\star}\end{array}$ & $\begin{array}{c}-0.199 \\
(0.083)^{\star}\end{array}$ & $\begin{array}{c}-0.260 \\
(0.082)^{\star}\end{array}$ & & & & $\begin{array}{c}-0.288 \\
(0.079)^{\star}\end{array}$ & $\begin{array}{c}-0.300 \\
(0.083)^{\star}\end{array}$ & $\begin{array}{c}-0.456 \\
(0.084)^{\star}\end{array}$ \\
\hline W_COLLARS & & & & & $\begin{array}{l}-0.127 \\
(0.708)\end{array}$ & $\begin{array}{l}-0.117 \\
(0.746)\end{array}$ & & & & & $\begin{array}{l}-0.359 \\
(0.533)\end{array}$ & $\begin{array}{l}-0.336 \\
(0.593)\end{array}$ \\
\hline GRADUATES & & & & & $\begin{array}{l}-0.015 \\
(0.932)\end{array}$ & $\begin{array}{l}-0.007 \\
(0.971)\end{array}$ & & & & & $\begin{array}{c}-0.667 \\
(0.032)^{\star \star}\end{array}$ & $\begin{array}{c}-0.651 \\
(0.072)^{\star}\end{array}$ \\
\hline INDUSTRY & no & no & no & no & no & no & yes & yes & yes & yes & yes & yes \\
\hline PROVINCE & no & no & no & no & no & no & yes & yes & yes & yes & yes & yes \\
\hline Obs. & 614 & 613 & 554 & 605 & 541 & 487 & 397 & 397 & 363 & 390 & 335 & 307 \\
\hline P-value & $0.000^{\star \star \star \star}$ & $0.000^{\star \star \star \star}$ & $0.000^{\star \star \star *}$ & $0.000^{\star \star \star}$ & $0.000^{\star \star \star}$ & $0.000^{\star \star \star *}$ & $0.000^{\star \star \star *}$ & $0.000^{\star \star \star}$ & $0.000^{\star \star \star *}$ & $0.000^{\star \star \star}$ & $0.000^{\star \star \star *}$ & $0.002^{\star \star \star}$ \\
\hline Pseudo R2 & 0.129 & 0.139 & 0.143 & 0.135 & 0.138 & 0.152 & 0.27 & 0.283 & 0.294 & 0.277 & 0.299 & 0.327 \\
\hline
\end{tabular}

\section{Conclusion}

This paper makes an empirical assessment over the boundaries of the multinational enterprise. Based on Italian microeconomic data, we analyze the trade-off between international outsourcing and foreign direct investment under contractual incompleteness. We believe our estimates comprise a few novelties, compared with the existing literature. First, this is an empirical study, while the great bulk of the International Economics treatment of hold-up and CI has been theoretical so far. Second, we depart from the few 
empirical contributions by using firm- rather than industry- or country-level information and we provide fresh evidence about Italian internationalization worldwide, differently from a literature very much focused on the US. Third, our econometric specifications rely on alternative measures of contractual incompleteness, that are included in the international outsourcing equation; this results in a more direct test of the CI argument, with respect to Antras (2003), Yeaple (2006), Tomiura (2007), Nunn and Trefler (2008), and Corcos et al. (2008). Last but not least, our findings contradict the general wisdom that MNEs operating in highly relation-specific environments are more prone to FDI relative to international outsourcing (as in Antras 2003; Grossman and Helpman 2003; Antras and Helpman 2004; Ottaviano and Turrini 2007), but they are in line with the most recent contribution due to Antras and Helpman (2008). This evidence is robust to different econometric specifications and alternative measures of contractual incompleteness and international outsourcing.

Given these promising findings, we believe that further research should be encouraged to go deeper into the boundaries of the multinational enterprise. In our view, future steps should include the collection of detailed microeconomic data about the MNEs' production process and input supply, to provide firm-level indicators of contractual incompleteness. Moreover, the availability of cross-country databases would help control for country, adding to industry and province fixed effects, and build alternative indexes of relation specificity, such as judicial quality. Hopefully, these extensions would shed more light on the trade-off between international outsourcing and foreign direct investment in a context of contractual incompleteness.

\section{Acknowledgments}

This paper is part of the project "International Fragmentation of Production. New Organizational Modes and the Role of Information Technologies". Data have been gathered with the help of Alfredo Minerva and Lorenzo Casaburi. The author is grateful to Gianmarco Ottaviano, Alessandro Sembenelli, Giorgio Barba Navaretti, Alessandra Tucci, and participants in seminars at Bocconi University, University of Milan Bicocca, Tor Vergata University, LUISS University, Turin University and Aarhus Business School for useful comments and insightful discussions. Financial support from the Italian 
Ministry of University and Research (MIUR) and University of Milan Bicocca is gratefully acknowledged. 


\section{References}

Acemoglu D, Antras P, Helpman E (2007) Contracts and Technology Adoption. American Economic Review 97: 916-943

Antras P (2003) Firms, Contracts, and Trade Structure. Quarterly Journal of Economics 118(4): 1375-1418

Antras P, Helpman E (2004) Global Sourcing. Journal of Political Economy 112(3): 552580

Antras P, Helpman E (2008) Contractual Frictions and Global Sourcing. In: Helpman E, Marin D, Verdier T (eds) The Organization of Firms in a Global Economy. Harvard University Press, Cambridge, Ma, pp 9-54

Barba Navaretti G, Venables AJ (2004) Multinational Firms in the World Economy. Princeton University Press, Princeton

Bernard AB, Jensen JB, Redding SJ, Schott PK (2010) Intrafirm Trade and Product Contractibility. American Economic Review Papers \& Proceedings 100(2): 444-448

Brainard SL (1997) An Empirical Assessment of the Proximity-Concentration Trade-off between Multinational Sales and Trade. American Economic Review 87: 520-544

Castellani D (2007) L’internazionalizzazione della produzione in Italia: caratteristiche delle imprese ed effetti sul sistema economico. L’Industria 28(3): 467-493

Coase RH (1937) The Nature of the Firm. Economica 4: 386-405

Corcos G, Irac DM, Mion G, Verdier T (2008) The Determinants of Intra-Firm Trade. Luca D’Agliano Working Paper 267

De Benedictis L, Giovannetti G (a cura di) (2008) Caratteristiche dell'internazionalizzazione delle imprese in Italia. Esportazioni, delocalizzazione e investimenti diretti all'estero. Rapporto CER-ICE, Soneria Mannelli, Rubbettino Editore

Ellison G, Glaeser EL, Kerr W (2010) What causes industry agglomeration? Evidence from coagglomeration patterns. American Economic Review 100(3): 1195-1213

Gattai V (2006) From the Theory of the Firm to FDI and Internalisation: a Survey. Il Giornale degli Economisti e Annali di Economia, 65(2): 225-262

Grossman GM, Hart OD (1986) The Costs and Benefits of Ownership: a Theory of Vertical and Lateral Integration. Journal of Political Economy 94(4): 691-719 
Grossman GM, Helpman E (2003) Outsourcing vs FDI in Industry Equilibrium. Journal of the European Economic Association 1: 317-327

Grout P (1984) Investment and Wages in the Absence of Binding Contracts: a Nash Bargaining Approach. Econometrica 52(2): 449-460

Hart OD (1995) Firms, Contracts, and Financial Structure. Oxford University Press, Oxford

Hart OD, Moore J (1990) Property rights \& the Nature of the Firms. Journal of Political Economy 98: 1119-1158

Helpman E (2006) Trade, FDI and the Organization of Firms. Journal of Economic Literature 44: 589-630

IMF (1993) Balance of Payments Manual, 5th edn. IMF, Washington DC

Levinsohn J, Petrin A (2003) Estimating Production Functions Using Inputs to Control for Unobservables. Review of Economic Studies April: 317-342

Mariotti S, Piscitello L, Elia S (2010) Spatial Agglomeration of Multinational Enterprises: The Role of Information Externalities and Knowledge Spillovers. Journal of Economic Geography 10: 519-538

Markusen JR (1995) The Boundaries of Multinational Enterprises and the Theory of International Trade. Journal of Economic Perspectives 9: 169-189

Melitz MJ (2003) The impact of Trade on Intra-Industry reallocations and Aggregate Industry Productivity. Econometrica 71(6): 1661-1694

Nunn N (2007) Relationship-Specificity, Incomplete Contracts and the Pattern of Trade. Quarterly Journal of Economics 122(2): 569-600

Nunn N, Trefler D (2008) The Boundaries of the Multinational Firm: An Empirical Analysis. In: Helpman E, Marin D, Verdier T (eds) The Organization of Firms in a Global Economy. Harvard University Press, Cambridge, Ma, pp 55-83

OECD (1996) OECD Benchmark Definition of Foreign Direct Investment, 3rd edn. OECD, Paris

Olley GS, Pakes A (1996) The Dynamics of Productivity in the Telecommunications Equipment Industry. Econometrica 64(6): 1263-1297

Ottaviano GIP, Turrini A (2007) Distance and FDI when Contracts are Incomplete. Journal of the European Economic Association 5: 796-822 
Rauch J (1999) Networks vs. Markets in International Trade. Journal of International Economics 48: 7-35

Smarzynska Javorcik BK (2004) Does Foreign Direct Investment Increase the Productivity of Domestic Firms? In Search of Spillovers Through Backward and Forward Linkages. American Economic Review 94: 605-627

Tadelis S, Williamson O (2012) Transaction Cost Economics. In: Gibbons R, Roberts J. (eds) Handobook of Organizational Economics. Forthcoming

Teece D J (1986) Transaction Cost Economics and the Multinational Enterprise. Journal of Economic Behaviour and Organization 7: 21-45

Tirole J (1999) Incomplete Contracts: Where do we Stand?. Econometrica 67(4): 741-781

Tomiura E (2007) Foreign Outsourcing, Exporting and FDI: A Productivity Comparison at the Firm Level. Journal of International Economics 72: 113-127

Williamson O (1975) Markets and Hierarchies. Free Press, New York

Yeaple SR (2006) Offshoring, Foreign Direct Investment, and the Structure of U.S. Trade. Journal of the European Economic Association (Papers and Proceedings) 4: 602-611

Zeile WJ (1997) US Intrafirm Trade in Goods. Survey of Current Business 77(2): 23-38 


\section{Appendix}

This section provides some further details about the empirical analysis. Table 4 displays the industry-level degree of contractual incompleteness and rank in 1998 and 2001, as computed in this paper. Tables 5 and 6 report summary statistics and correlations for the main variables employed for econometric purposes. Tables 7 and 8 complement the empirical analysis in the main text, by regressing OUT and BUY on CI_CONSERV instead of CI_LIBERAL.

Table 4: Industry-level degree of contractual incompleteness and rank in 1998 and 2001

\begin{tabular}{|c|c|c|c|c|}
\hline Industry & $\begin{array}{c}C I \\
\_L I B E R A L \\
1998\end{array}$ & $\begin{array}{c}C I \\
\text { _LIBERAL } \\
2001\end{array}$ & $\begin{array}{r}\text { Rank } \\
1998\end{array}$ & $\begin{array}{c}\text { Rank } \\
2001\end{array}$ \\
\hline Other transport equipment & 0.899 & 0.903 & 2 & 1 \\
\hline Office machinery and computers & 0.931 & 0.894 & 1 & 2 \\
\hline Television and radio receivers, sound or video recording or reproducing apparatus and associated goods & 0.889 & 0.859 & 3 & 3 \\
\hline Footwear & 0.852 & 0.836 & 5 & 4 \\
\hline Medical, precision and optical instruments, watches and clocks & 0.842 & 0.829 & 6 & 5 \\
\hline Building and repairing of ships and boats & 0.853 & 0.810 & 4 & 6 \\
\hline Agricultural and forestry machinery & 0.794 & 0.806 & 10 & 7 \\
\hline Motor vehicles, trailers and semi-trailers & 0.759 & 0.785 & 13 & 8 \\
\hline Electric motors, generators and transformers; manufacture of electricity distribution and control apparatus & 0.792 & 0.776 & 11 & 9 \\
\hline Electronic valves and tubes and other electronic components & 0.818 & 0.772 & 7 & 10 \\
\hline Aircraft and spacecraft & 0.809 & 0.771 & 8 & 11 \\
\hline Wearing apparel; dressing and dyeing of fur & 0.768 & 0.769 & 12 & 12 \\
\hline Television and radio transmitters and apparatus for line telephony and line telegraphy & 0.800 & 0.749 & 9 & 13 \\
\hline Glass and glass products & 0.725 & 0.727 & 17 & 14 \\
\hline Miscellaneous manufacturing not elsewhere classified; recycling & 0.714 & 0.720 & 18 & 15 \\
\hline Publishing, printing and reproduction of recorded media & 0.679 & 0.713 & 24 & 16 \\
\hline Soap and detergents, cleaning and polishing preparations, perfumes and toilet preparations & 0.745 & 0.711 & 16 & 17 \\
\hline Mining of coal and lignite; extraction of peat & 0.755 & 0.694 & 14 & 18 \\
\hline Other general purpose machinery & 0.708 & 0.689 & 20 & 19 \\
\hline Pharmaceuticals, medicinal chemicals and botanical products & 0.670 & 0.683 & 25 & 20 \\
\hline Machine tools & 0.713 & 0.679 & 19 & 21 \\
\hline Machinery for the production and use of mechanical power, except aircraft, vehicle and cycle engines & 0.689 & 0.678 & 22 & 22 \\
\hline Ceramic goods & 0.687 & 0.677 & 23 & 23 \\
\hline Electrical equipment not elsewhere classified & 0.694 & 0.664 & 21 & 24 \\
\hline Furniture & 0.610 & 0.654 & 28 & 25 \\
\hline Other special purpose machinery & 0.644 & 0.654 & 26 & 26 \\
\hline Sports goods, games and toys & 0.747 & 0.654 & 15 & 27 \\
\hline Tanks, reservoirs and containers of metal; central heating radiators and boilers; steam generators & 0.573 & 0.649 & 33 & 28 \\
\hline Made-up textile articles, except apparel & 0.587 & 0.638 & 31 & 29 \\
\hline Rubber products & 0.587 & 0.629 & 32 & 30 \\
\hline Plastic products & 0.604 & 0.602 & 29 & 31 \\
\hline Production of mineral waters and soft drinks & 0.599 & 0.584 & 30 & 32 \\
\hline Domestic appliances not elsewhere classified & 0.567 & 0.583 & 35 & 33 \\
\hline
\end{tabular}




\begin{tabular}{|c|c|c|c|c|}
\hline Bricks, tiles and construction products in baked clay & 0.625 & 0.574 & 27 & 34 \\
\hline Basic iron and steel and of ferro-alloys; manufacture of tubes and other first processing of iron and steel & 0.491 & 0.554 & 42 & 35 \\
\hline Wood and wood products, except furniture & 0.549 & 0.547 & 36 & 36 \\
\hline Alcoholic beverages - alcohol and malt & 0.506 & 0.515 & 40 & 37 \\
\hline Dairy products & 0.510 & 0.509 & 39 & 38 \\
\hline Casting of metals & 0.516 & 0.502 & 37 & 39 \\
\hline Cement, lime and plaster & 0.572 & 0.495 & 34 & 40 \\
\hline Cutlery, tools and general hardware & 0.473 & 0.490 & 43 & 41 \\
\hline Other food products & 0.511 & 0.483 & 38 & 42 \\
\hline Insulated wire and cable & 0.447 & 0.475 & 45 & 43 \\
\hline Grain mill products, starches and starch products & 0.499 & 0.463 & 41 & 44 \\
\hline Structural metal products & 0.467 & 0.446 & 44 & 45 \\
\hline Other textiles & 0.421 & 0.433 & 47 & 46 \\
\hline Knitted and crocheted fabrics and articles & 0.335 & 0.417 & 58 & 47 \\
\hline Cocoa; chocolate and sugar confectionery & 0.413 & 0.409 & 48 & 48 \\
\hline Bread, rusks and biscuits; pastry goods and cakes & 0.383 & 0.400 & 52 & 49 \\
\hline Processing and preserving of fish and fish products; fruit and vegetables & 0.407 & 0.397 & 49 & 50 \\
\hline Articles of plaster and cement; cutting, shaping and finishing of stone & 0.392 & 0.387 & 51 & 51 \\
\hline Paints, varnishes and similar coatings, printing ink and mastics & 0.396 & 0.363 & 50 & 52 \\
\hline Prepared animal feeds & 0.437 & 0.355 & 46 & 53 \\
\hline Production, processing and preserving of meat and meat products & 0.361 & 0.346 & 53 & 54 \\
\hline Other fabricated metal products & 0.361 & 0.345 & 54 & 55 \\
\hline Sugar & 0.338 & 0.342 & 56 & 56 \\
\hline Textile weaving & 0.284 & 0.322 & 65 & 57 \\
\hline Forging, pressing, stamping and roll forming of metal; powder metallurgy; treatment of metals & 0.342 & 0.318 & 55 & 58 \\
\hline Carpets and rugs & 0.338 & 0.315 & 57 & 59 \\
\hline Other chemical products & 0.262 & 0.295 & 67 & 60 \\
\hline Articles of paper and paperboard & 0.292 & 0.286 & 62 & 61 \\
\hline Jewellery and related articles; musical instruments & 0.179 & 0.279 & 72 & 62 \\
\hline Tanning and dressing of leather; luggage, handbags, saddlery and harness & 0.309 & 0.278 & 60 & 63 \\
\hline Pesticides and other agro-chemical products & 0.194 & 0.269 & 71 & 64 \\
\hline Pulp, paper and paperboard & 0.293 & 0.263 & 61 & 65 \\
\hline Fertilisers and nitrogen compounds & 0.289 & 0.253 & 64 & 66 \\
\hline Other inorganic basic chemicals & 0.276 & 0.224 & 66 & 67 \\
\hline Preparation and spinning of textile fibres & 0.220 & 0.221 & 69 & 68 \\
\hline Vegetable and animal oils and fats & 0.290 & 0.217 & 63 & 69 \\
\hline Man-made fibres & 0.326 & 0.197 & 59 & 70 \\
\hline Plastics and synthetic rubber in primary forms & 0.201 & 0.162 & 70 & 71 \\
\hline Basic precious and non-ferrous metals & 0.170 & 0.155 & 73 & 72 \\
\hline Industrial gases, dyes and pigments & 0.221 & 0.155 & 68 & 73 \\
\hline Other organic basic chemicals & 0.145 & 0.103 & 74 & 74 \\
\hline Coke, refined petroleum products and nuclear fuel & 0.035 & 0.040 & 75 & 75 \\
\hline
\end{tabular}


Table 5: Summary statistics

\begin{tabular}{|c|c|c|c|c|c|}
\hline Variable & Obs. & Mean & Std.Dev. & Min & Max \\
\hline CI_LIBERAL & 7749 & 0.5440 & 0.1871 & 0.0350 & 0.9310 \\
\hline CI_CONSERV & 7749 & 0.6063 & 0.1967 & 0.0361 & 0.9693 \\
\hline EMPLOYEES & 7896 & 0.1069 & 0.3768 & 0.011 & 12.63 \\
\hline$T F P$ & 7230 & 4.7962 & 0.7595 & 0.7595 & 9.0798 \\
\hline$A G E$ & 7709 & 3.1346 & 0.6819 & 0 & 7.6029 \\
\hline GROUP & 7880 & 0.2453 & 0.4302 & 0 & 1 \\
\hline EXPERIENCE & 7896 & 0.1606 & 0.3672 & 0 & 1 \\
\hline BANKS & 3329 & 5.7360 & 3.4430 & 1 & 25 \\
\hline LISTED & 3372 & 0.9839 & 0.6221 & 0 & 1 \\
\hline GRADUATES & 5136 & 0.0589 & 0.0733 & 0 & 0.9 \\
\hline W_COLLARS & 7896 & 0.0169 & 0.0371 & 0.0371 & 0.5555 \\
\hline H_SKILLED & 5139 & 0.0505 & 0.0796 & 0 & 1 \\
\hline$R \& D \_I N V$ & 7763 & 0.4132 & 0.4924 & 0 & 1 \\
\hline$I C T \_I N V$ & 7164 & 0.8030 & 0.3977 & 0 & 1 \\
\hline INNOVATION & 3341 & 0.6444 & 0.4788 & 0 & 1 \\
\hline
\end{tabular}


Table 6: Correlation matrix

\begin{tabular}{|c|c|c|c|c|c|c|c|c|c|c|c|c|c|c|c|}
\hline & 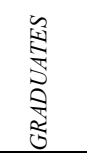 & 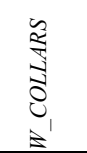 & 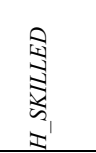 & 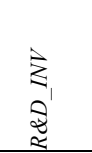 & 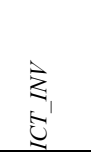 & \begin{tabular}{l}
$\vdots$ \\
$\vdots$ \\
\multirow{3}{*}{} \\
0 \\
$\vdots$ \\
$\vdots$
\end{tabular} & 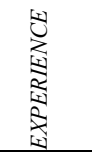 & 标 & 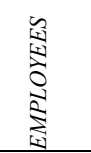 & 넝 & 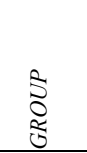 & 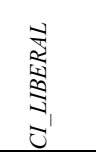 & 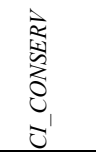 & 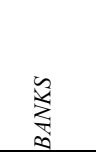 & 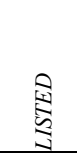 \\
\hline GRADUATES & 1.0000 & & & & & & & & & & & & & & \\
\hline$W_{-} C O L L A R S$ & 0.2516 & 1.0000 & & & & & & & & & & & & & \\
\hline H_SKILLED & 0.2405 & 0.0640 & 1.0000 & & & & & & & & & & & & \\
\hline$R \& D \_I N V$ & 0.1921 & 0.1108 & 0.4728 & 1.0000 & & & & & & & & & & & \\
\hline$I C T \_I N V$ & 0.0640 & 0.0198 & 0.0924 & 0.2142 & 1.0000 & & & & & & & & & & \\
\hline INNOVATION & 0.1326 & 0.0720 & 0.2360 & 0.3805 & 0.1211 & 1.0000 & & & & & & & & & \\
\hline EXPERIENCE & 0.1589 & 0.0831 & 0.1812 & 0.3290 & 0.1588 & 0.2147 & 1.0000 & & & & & & & & \\
\hline$T F P$ & 0.2663 & 0.2113 & 0.0833 & 0.2038 & 0.0506 & 0.1194 & 0.1461 & 1.0000 & & & & & & & \\
\hline EMPLOYEES & 0.0605 & 0.0589 & -0.0006 & 0.1178 & 0.0461 & 0.0789 & 0.1115 & 0.2148 & 1.0000 & & & & & & \\
\hline$A G E$ & 0.0212 & 0.0268 & 0.0206 & 0.0578 & 0.0636 & 0.0292 & 0.0001 & 0.0501 & 0.0471 & 1.0000 & & & & & \\
\hline GROUP & 0.2104 & 0.1707 & 0.0514 & 0.1584 & 0.0740 & 0.0932 & 0.1295 & 0.2745 & 0.0275 & -0.0627 & 1.0000 & & & & \\
\hline CI_LIBERAL & 0.1233 & 0.0274 & 0.1343 & 0.1612 & 0.0590 & 0.0958 & 0.1306 & 0.1495 & 0.0671 & -0.0430 & 0.0726 & 1.0000 & & & \\
\hline CI_CONSERV & 0.1401 & 0.0217 & 0.1497 & 0.1545 & 0.0619 & 0.1012 & 0.058 & 0.1103 & 0.062 & -0.0500 & 0.0519 & 0.9727 & 1.0000 & & \\
\hline BANKS & 0.0841 & 0.0786 & 0.0647 & 0.2077 & 0.1040 & 0.0957 & 0.1497 & 0.2088 & 0.1298 & 0.0847 & 0.1791 & 0.0088 & -0.0056 & 1.0000 & \\
\hline LISTED & -0.0987 & -0.0599 & -0.0245 & -0.0348 & -0.0260 & -0.0148 & -0.0335 & -0.1076 & -0.0868 & 0.0389 & -0.1271 & -0.0164 & -0.0192 & -0.0208 & 1.0000 \\
\hline
\end{tabular}


Table 7: Probit estimates of equations 1 (left) and 4 (right), with dependent variable OUT, conservative definition of contractual incompleteness ${ }^{15}$

\begin{tabular}{|c|c|c|c|c|c|c|c|c|c|c|c|c|}
\hline & \multicolumn{6}{|c|}{ basic specification } & \multicolumn{6}{|c|}{ robustness check } \\
\hline & $\begin{array}{c}\text { OUT } \\
(1) \\
\end{array}$ & $\begin{array}{l}\text { OUT } \\
(2) \\
\end{array}$ & $\begin{array}{c}\text { OUT } \\
(3) \\
\end{array}$ & $\begin{array}{l}\text { OUT } \\
(4) \\
\end{array}$ & $\begin{array}{c}\text { OUT } \\
(5) \\
\end{array}$ & $\begin{array}{c}\text { OUT } \\
(6) \\
\end{array}$ & $\begin{array}{c}\text { OUT } \\
(7) \\
\end{array}$ & $\begin{array}{l}\text { OUT } \\
(8) \\
\end{array}$ & $\begin{array}{c}\text { OUT } \\
(9) \\
\end{array}$ & $\begin{array}{l}\text { OUT } \\
(10) \\
\end{array}$ & $\begin{array}{l}\text { OUT } \\
(11) \\
\end{array}$ & $\begin{array}{l}\text { OUT } \\
(12) \\
\end{array}$ \\
\hline Cl_CONSERV & $\begin{array}{c}0.211 \\
(0.000)^{\star \star \star}\end{array}$ & $\begin{array}{c}0.199 \\
(0.000)^{\star \star \star}\end{array}$ & $\begin{array}{c}0.199 \\
(0.000)^{\star \star \star}\end{array}$ & $\begin{array}{c}0.206 \\
(0.000)^{\star \star \star}\end{array}$ & $\begin{array}{c}0.206 \\
(0.000)^{\star \star \star}\end{array}$ & $\begin{array}{c}0.200 \\
(0.000)^{\star \star \star}\end{array}$ & $\begin{array}{c}0.163 \\
(0.023)^{\star \star}\end{array}$ & $\begin{array}{c}0.155 \\
(0.030)^{\star \star}\end{array}$ & $\begin{array}{c}0.169 \\
(0.032)^{\star \star}\end{array}$ & $\begin{array}{c}0.153 \\
(0.034)^{\star \star}\end{array}$ & $\begin{array}{c}0.163 \\
(0.032)^{\star \star}\end{array}$ & $\begin{array}{c}0.180 \\
(0.032)^{\star \star}\end{array}$ \\
\hline TFP & $\begin{array}{c}-0.019 \\
(0.063)^{\star}\end{array}$ & $\begin{array}{c}-0.020 \\
(0.043)^{\star \star}\end{array}$ & $\begin{array}{l}-0.017 \\
(0.130)\end{array}$ & $\begin{array}{c}-0.019 \\
(0.058)^{\star}\end{array}$ & $\begin{array}{c}-0.020 \\
(0.072)^{\star}\end{array}$ & $\begin{array}{l}-0.016 \\
(0.191)\end{array}$ & $\begin{array}{l}-0.011 \\
(0.476)\end{array}$ & $\begin{array}{l}-0.012 \\
(0.439)\end{array}$ & $\begin{array}{l}-0.005 \\
(0.784)\end{array}$ & $\begin{array}{l}-0.011 \\
(0.488)\end{array}$ & $\begin{array}{l}-0.020 \\
(0.246)\end{array}$ & $\begin{array}{l}-0.013 \\
(0.474)\end{array}$ \\
\hline GROUP & $\begin{array}{c}0.019 \\
(0.250)\end{array}$ & $\begin{array}{c}0.016 \\
(0.310)\end{array}$ & $\begin{array}{c}0.014 \\
(0.448)\end{array}$ & $\begin{array}{c}0.018 \\
(0.285)\end{array}$ & $\begin{array}{c}0.024 \\
(0.183)\end{array}$ & $\begin{array}{c}0.014 \\
(0.464)\end{array}$ & $\begin{array}{c}0.020 \\
(0.244)\end{array}$ & $\begin{array}{c}0.018 \\
(0.303)\end{array}$ & $\begin{array}{c}0.012 \\
(0.511)\end{array}$ & $\begin{array}{c}0.018 \\
(0.295)\end{array}$ & $\begin{array}{c}0.024 \\
(0.203)\end{array}$ & $\begin{array}{c}0.013 \\
(0.519)\end{array}$ \\
\hline$A G E$ & $\begin{array}{c}0.018 \\
(0.081)^{\star}\end{array}$ & $\begin{array}{c}0.017 \\
(0.097)^{\star}\end{array}$ & $\begin{array}{c}0.018 \\
(0.116)\end{array}$ & $\begin{array}{c}0.019 \\
(0.070)^{\star}\end{array}$ & $\begin{array}{c}0.030 \\
(0.010)^{\star \star \star}\end{array}$ & $\begin{array}{c}0.026 \\
(0.042)^{\star \star}\end{array}$ & $\begin{array}{c}0.013 \\
(0.234)\end{array}$ & $\begin{array}{c}0.013 \\
(0.258)\end{array}$ & $\begin{array}{c}0.014 \\
(0.247)\end{array}$ & $\begin{array}{c}0.015 \\
(0.191)\end{array}$ & $\begin{array}{c}0.025 \\
(0.044)^{\star \star}\end{array}$ & $\begin{array}{c}0.022 \\
(0.109)\end{array}$ \\
\hline EMPLOYEES & $\begin{array}{c}0.052 \\
(0.003)^{\star \star \star}\end{array}$ & $\begin{array}{c}0.050 \\
(0.005)^{\star \star \star}\end{array}$ & $\begin{array}{c}0.051 \\
(0.006)^{\star \star \star}\end{array}$ & $\begin{array}{c}0.055 \\
(0.002)^{\star \star \star}\end{array}$ & $\begin{array}{c}0.026 \\
(0.229)\end{array}$ & $\begin{array}{c}0.022 \\
(0.313)\end{array}$ & $\begin{array}{c}0.046 \\
(0.015)^{\star \star}\end{array}$ & $\begin{array}{c}0.043 \\
(0.020)^{\star \star}\end{array}$ & $\begin{array}{c}0.041 \\
(0.032)^{\star \star}\end{array}$ & $\begin{array}{c}0.046 \\
(0.014)^{\star \star}\end{array}$ & $\begin{array}{c}0.014 \\
(0.517)\end{array}$ & $\begin{array}{c}0.009 \\
(0.686)\end{array}$ \\
\hline EXPERIENCE & $\begin{array}{c}0.072 \\
(0.000)^{\star \star \star}\end{array}$ & $\begin{array}{c}0.063 \\
(0.000)^{\star \star \star}\end{array}$ & $\begin{array}{c}0.056 \\
(0.001)^{\star \star \star}\end{array}$ & $\begin{array}{c}0.066 \\
(0.000)^{\star \star \star}\end{array}$ & $\begin{array}{c}0.062 \\
(0.000)^{\star \star \star}\end{array}$ & $\begin{array}{c}0.047 \\
(0.007)^{\star \star \star}\end{array}$ & $\begin{array}{c}0.076 \\
(0.000)^{\star \star \star}\end{array}$ & $\begin{array}{c}0.068 \\
(0.000)^{\star \star \star}\end{array}$ & $\begin{array}{c}0.061 \\
(0.000)^{\star \star \star}\end{array}$ & $\begin{array}{c}0.072 \\
(0.000)^{\star \star \star}\end{array}$ & $\begin{array}{c}0.070 \\
(0.000)^{\star \star \star}\end{array}$ & $\begin{array}{c}0.055 \\
(0.003)^{\star \star \star}\end{array}$ \\
\hline BANKS & $\begin{array}{c}0.005 \\
(0.020)^{\star \star}\end{array}$ & $\begin{array}{c}0.004 \\
(0.039)^{\star \star}\end{array}$ & $\begin{array}{c}0.003 \\
(0.159)\end{array}$ & $\begin{array}{c}0.005 \\
(0.019)^{\star \star}\end{array}$ & $\begin{array}{c}0.004 \\
(0.048)^{\star \star}\end{array}$ & $\begin{array}{c}0.003 \\
(0.283)\end{array}$ & $\begin{array}{c}0.004 \\
(0.050)^{\star \star}\end{array}$ & $\begin{array}{c}0.004 \\
(0.090)^{\star}\end{array}$ & $\begin{array}{c}0.002 \\
(0.290)\end{array}$ & $\begin{array}{c}0.004 \\
(0.046)^{\star \star}\end{array}$ & $\begin{array}{c}0.004 \\
(0.069)^{\star}\end{array}$ & $\begin{array}{c}0.002 \\
(0.385)\end{array}$ \\
\hline LISTED & $\begin{array}{l}-0.029 \\
(0.630)\end{array}$ & $\begin{array}{l}-0.029 \\
(0.627)\end{array}$ & $\begin{array}{l}-0.013 \\
(0.835)\end{array}$ & $\begin{array}{l}-0.049 \\
(0.420)\end{array}$ & $\begin{array}{l}-0.086 \\
(0.195)\end{array}$ & $\begin{array}{l}-0.077 \\
(0.278)\end{array}$ & $\begin{array}{l}-0.019 \\
(0.750)\end{array}$ & $\begin{array}{l}-0.019 \\
(0.756)\end{array}$ & $\begin{array}{l}-0.001 \\
(0.994)\end{array}$ & $\begin{array}{l}-0.038 \\
(0.536)\end{array}$ & $\begin{array}{l}-0.062 \\
(0.363)\end{array}$ & $\begin{array}{l}-0.046 \\
(0.532)\end{array}$ \\
\hline$R \& D \_I N V$ & & $\begin{array}{c}0.032 \\
(0.037)^{\star \star}\end{array}$ & $\begin{array}{c}0.003 \\
(0.856)\end{array}$ & & & $\begin{array}{c}0.010 \\
(0.617)\end{array}$ & & $\begin{array}{c}0.030 \\
(0.060)^{\star}\end{array}$ & $\begin{array}{c}0.004 \\
(0.840)\end{array}$ & & & $\begin{array}{c}0.013 \\
(0.546)\end{array}$ \\
\hline INNOVATION & & & $\begin{array}{c}0.055 \\
(0.003)^{\star \star \star}\end{array}$ & & & $\begin{array}{c}0.059 \\
(0.002)^{\star \star \star}\end{array}$ & & & $\begin{array}{c}0.058 \\
(0.002)^{\star \star \star}\end{array}$ & & & $\begin{array}{c}0.063 \\
(0.002)^{\star \star \star}\end{array}$ \\
\hline$I C T \_I N V$ & & & $\begin{array}{c}0.046 \\
(0.018)^{\star \star}\end{array}$ & & & $\begin{array}{c}0.055 \\
(0.008)^{\star \star \star}\end{array}$ & & & $\begin{array}{c}0.040 \\
(0.052)^{\star}\end{array}$ & & & $\begin{array}{c}0.050 \\
(0.023)^{\star \star}\end{array}$ \\
\hline H_SKILLED & & & & $\begin{array}{c}0.099 \\
(0.289)\end{array}$ & $\begin{array}{c}0.093 \\
(0.341)\end{array}$ & $\begin{array}{l}-0.096 \\
(0.447)\end{array}$ & & & & $\begin{array}{c}0.065 \\
(0.501)\end{array}$ & $\begin{array}{c}0.045 \\
(0.659)\end{array}$ & $\begin{array}{l}-0.166 \\
(0.212)\end{array}$ \\
\hline W_COLLARS & & & & & $\begin{array}{c}0.022 \\
(0.920)\end{array}$ & $\begin{array}{c}0.019 \\
(0.937)\end{array}$ & & & & & $\begin{array}{c}0.065 \\
(0.783)\end{array}$ & $\begin{array}{c}0.080 \\
(0.755)\end{array}$ \\
\hline GRADUATES & & & & & $\begin{array}{l}-0.097 \\
(0.395)\end{array}$ & $\begin{array}{l}-0.122 \\
(0.336)\end{array}$ & & & & & $\begin{array}{l}-0.062 \\
(0.609)\end{array}$ & $\begin{array}{l}-0.084 \\
(0.540)\end{array}$ \\
\hline INDUSTRY & no & no & no & no & no & no & yes & yes & yes & yes & yes & yes \\
\hline PROVINCE & no & no & no & no & no & no & yes & yes & yes & yes & yes & yes \\
\hline Obs. & 3090 & 3089 & 2650 & 3059 & 2746 & 2358 & 3024 & 3023 & 2594 & 2995 & 2658 & 2278 \\
\hline P-value & $0.000^{\star \star \star}$ & $0.000^{\star \star \star}$ & $0.000^{\star \star \star *}$ & $0.000^{\star \star \star}$ & $0.000^{\star \star \star}$ & $0.000^{\star \star \star}$ & $0.000^{\star \star \star}$ & $0.000^{\star \star \star}$ & $0.000^{\star \star \star}$ & $0.000^{\star \star \star}$ & $0.003^{\star \star \star}$ & $0.008^{\star \star \star}$ \\
\hline Pseudo R2 & 0.032 & 0.034 & 0.038 & 0.032 & 0.028 & 0.034 & 0.064 & 0.065 & 0.07 & 0.065 & 0.062 & 0.068 \\
\hline
\end{tabular}


Table 8: Probit estimates of equations 1 (left) and 4 (right), with dependent variable BUY, conservative definition of contractual incompleteness ${ }^{15}$

\begin{tabular}{|c|c|c|c|c|c|c|c|c|c|c|c|c|}
\hline & \multicolumn{6}{|c|}{ basic specification } & \multicolumn{6}{|c|}{ robustness check } \\
\hline & $\begin{array}{c}B U Y \\
(1) \\
\end{array}$ & $\begin{array}{c}B U Y \\
(2) \\
\end{array}$ & $\begin{array}{c}B U Y \\
(3) \\
\end{array}$ & $\begin{array}{c}B U Y \\
(4) \\
\end{array}$ & $\begin{array}{c}B U Y \\
(5) \\
\end{array}$ & $\begin{array}{c}B U Y \\
(6)\end{array}$ & $\begin{array}{c}B U Y \\
(7) \\
\end{array}$ & $\begin{array}{c}B U Y \\
(8) \\
\end{array}$ & $\begin{array}{c}B U Y \\
(9) \\
\end{array}$ & $\begin{array}{l}B U Y \\
(10) \\
\end{array}$ & $\begin{array}{l}B U Y \\
(11)\end{array}$ & $\begin{array}{l}B U Y \\
(12) \\
\end{array}$ \\
\hline Cl_CONSERV & $\begin{array}{c}0.140 \\
(0.023)^{\star \star}\end{array}$ & $\begin{array}{c}0.158 \\
(0.010)^{\star \star \star}\end{array}$ & $\begin{array}{c}0.163 \\
(0.014)^{\star \star}\end{array}$ & $\begin{array}{c}0.152 \\
(0.014)^{\star \star}\end{array}$ & $\begin{array}{c}0.150 \\
(0.024)^{\star \star}\end{array}$ & $\begin{array}{c}0.167 \\
(0.021)^{\star \star}\end{array}$ & $\begin{array}{c}0.311 \\
(0.047)^{\star \star}\end{array}$ & $\begin{array}{c}0.335 \\
(0.017)^{\star \star}\end{array}$ & $\begin{array}{c}0.353 \\
(0.016)^{\star \star}\end{array}$ & $\begin{array}{c}0.251 \\
(0.024)^{\star \star}\end{array}$ & $\begin{array}{c}0.259 \\
(0.042)^{\star \star}\end{array}$ & $\begin{array}{c}0.299 \\
(0.089)^{\star}\end{array}$ \\
\hline TFP & $\begin{array}{l}-0.003 \\
(0.834)\end{array}$ & $\begin{array}{l}-0.006 \\
(0.711)\end{array}$ & $\begin{array}{l}-0.011 \\
(0.531)\end{array}$ & $\begin{array}{l}-0.002 \\
(0.884)\end{array}$ & $\begin{array}{l}-0.008 \\
(0.651)\end{array}$ & $\begin{array}{l}-0.014 \\
(0.461)\end{array}$ & $\begin{array}{l}-0.009 \\
(0.829)\end{array}$ & $\begin{array}{l}-0.005 \\
(0.912)\end{array}$ & $\begin{array}{l}-0.017 \\
(0.702)\end{array}$ & $\begin{array}{l}-0.013 \\
(0.763)\end{array}$ & $\begin{array}{l}-0.003 \\
(0.948)\end{array}$ & $\begin{array}{l}-0.018 \\
(0.731)\end{array}$ \\
\hline GROUP & $\begin{array}{c}-0.084 \\
(0.002)^{\star \star \star}\end{array}$ & $\begin{array}{c}-0.076 \\
(0.005)^{\star \star \star}\end{array}$ & $\begin{array}{c}-0.074 \\
(0.011)^{\star \star}\end{array}$ & $\begin{array}{c}-0.082 \\
(0.003)^{\star \star \star}\end{array}$ & $\begin{array}{c}-0.074 \\
(0.014)^{\star \star}\end{array}$ & $\begin{array}{c}-0.067 \\
(0.036)^{\star \star}\end{array}$ & $\begin{array}{c}-0.151 \\
(0.001)^{\star \star \star}\end{array}$ & $\begin{array}{c}-0.142 \\
(0.001)^{\star \star \star}\end{array}$ & $\begin{array}{c}-0.144 \\
(0.003)^{\star \star \star}\end{array}$ & $\begin{array}{c}-0.149 \\
(0.001)^{\star \star \star}\end{array}$ & $\begin{array}{c}-0.116 \\
(0.016)^{\star \star}\end{array}$ & $\begin{array}{c}-0.110 \\
(0.035)^{\star \star}\end{array}$ \\
\hline$A G E$ & $\begin{array}{l}-0.004 \\
(0.834)\end{array}$ & $\begin{array}{l}-0.001 \\
(0.941)\end{array}$ & $\begin{array}{l}-0.007 \\
(0.710)\end{array}$ & $\begin{array}{l}-0.008 \\
(0.636)\end{array}$ & $\begin{array}{l}-0.002 \\
(0.912)\end{array}$ & $\begin{array}{l}-0.003 \\
(0.514)\end{array}$ & $\begin{array}{l}-0.005 \\
(0.847)\end{array}$ & $\begin{array}{l}-0.008 \\
(0.752)\end{array}$ & $\begin{array}{l}-0.022 \\
(0.429)\end{array}$ & $\begin{array}{l}-0.001 \\
(0.985)\end{array}$ & $\begin{array}{l}-0.005 \\
(0.858)\end{array}$ & $\begin{array}{l}-0.027 \\
(0.384)\end{array}$ \\
\hline EMPLOYEES & $\begin{array}{l}-0.023 \\
(0.422)\end{array}$ & $\begin{array}{l}-0.024 \\
(0.379)\end{array}$ & $\begin{array}{l}-0.020 \\
(0.506)\end{array}$ & $\begin{array}{l}-0.023 \\
(0.416)\end{array}$ & $\begin{array}{l}-0.002 \\
(0.959)\end{array}$ & $\begin{array}{l}-0.007 \\
(0.831)\end{array}$ & $\begin{array}{l}-0.019 \\
(0.662)\end{array}$ & $\begin{array}{l}-0.011 \\
(0.796)\end{array}$ & $\begin{array}{l}-0.003 \\
(0.953)\end{array}$ & $\begin{array}{l}-0.017 \\
(0.687)\end{array}$ & $\begin{array}{l}-0.006 \\
(0.887)\end{array}$ & $\begin{array}{l}-0.010 \\
(0.840)\end{array}$ \\
\hline EXPERIENCE & $\begin{array}{c}-0.116 \\
(0.000)^{\star \star \star}\end{array}$ & $\begin{array}{c}-0.098 \\
(0.000)^{\star \star \star}\end{array}$ & $\begin{array}{c}-0.099 \\
(0.001)^{\star \star \star}\end{array}$ & $\begin{array}{c}-0.110 \\
(0.000)^{\star \star \star}\end{array}$ & $\begin{array}{c}-0.116 \\
(0.000)^{\star \star \star}\end{array}$ & $\begin{array}{c}-0.107 \\
(0.001)^{\star \star \star}\end{array}$ & $\begin{array}{c}-0.147 \\
(0.000)^{\star \star \star}\end{array}$ & $\begin{array}{c}-0.111 \\
(0.005)^{\star \star \star}\end{array}$ & $\begin{array}{c}-0.112 \\
(0.010)^{\star \star \star}\end{array}$ & $\begin{array}{c}-0.137 \\
(0.001)^{\star \star \star}\end{array}$ & $\begin{array}{c}-0.134 \\
(0.002)^{\star \star \star}\end{array}$ & $\begin{array}{c}-0.115 \\
(0.015)^{\star \star}\end{array}$ \\
\hline BANKS & $\begin{array}{c}-0.009 \\
(0.001)^{\star \star \star}\end{array}$ & $\begin{array}{c}-0.009 \\
(0.001)^{\star \star \star}\end{array}$ & $\begin{array}{c}-0.009 \\
(0.002)^{\star \star \star}\end{array}$ & $\begin{array}{c}-0.009 \\
(0.002)^{\star \star \star}\end{array}$ & $\begin{array}{c}-0.009 \\
(0.004)^{\star \star \star}\end{array}$ & $\begin{array}{c}-0.008 \\
(0.009)^{\star \star \star}\end{array}$ & $\begin{array}{c}-0.014 \\
(0.002)^{\star \star \star}\end{array}$ & $\begin{array}{c}-0.013 \\
(0.002)^{\star \star \star}\end{array}$ & $\begin{array}{c}-0.014 \\
(0.002)^{\star \star \star}\end{array}$ & $\begin{array}{c}-0.012 \\
(0.004)^{\star \star \star}\end{array}$ & $\begin{array}{c}-0.012 \\
(0.007)^{\star \star \star}\end{array}$ & $\begin{array}{c}-0.012 \\
(0.010)^{\star \star \star}\end{array}$ \\
\hline LISTED & $\begin{array}{c}0.006 \\
(0.940)\end{array}$ & $\begin{array}{c}0.006 \\
(0.935)\end{array}$ & $\begin{array}{c}0.017 \\
(0.843)\end{array}$ & $\begin{array}{c}0.006 \\
(0.934)\end{array}$ & $\begin{array}{c}0.032 \\
(0.713)\end{array}$ & $\begin{array}{c}0.027 \\
(0.773)\end{array}$ & $\begin{array}{c}0.131 \\
(0.332)\end{array}$ & $\begin{array}{c}0.114 \\
(0.387)\end{array}$ & $\begin{array}{c}0.174 \\
(0.229)\end{array}$ & $\begin{array}{c}0.121 \\
(0.361)\end{array}$ & $\begin{array}{c}0.103 \\
(0.460)\end{array}$ & $\begin{array}{c}0.142 \\
(0.315)\end{array}$ \\
\hline$R \& D \_I N V$ & & $\begin{array}{c}-0.059 \\
(0.024)^{\star \star}\end{array}$ & $\begin{array}{c}-0.070 \\
(0.020)^{\star \star \star}\end{array}$ & & & $\begin{array}{l}-0.046 \\
(0.175)\end{array}$ & & $\begin{array}{c}-0.094 \\
(0.027)^{\star \star}\end{array}$ & $\begin{array}{c}-0.108 \\
(0.021)^{\star \star}\end{array}$ & & & $\begin{array}{l}-0.072 \\
(0.183)\end{array}$ \\
\hline INNOVATION & & & $\begin{array}{c}0.055 \\
(0.158)\end{array}$ & & & $\begin{array}{c}0.066 \\
(0.120)\end{array}$ & & & $\begin{array}{c}0.107 \\
(0.089)^{\star}\end{array}$ & & & $\begin{array}{c}0.143 \\
(0.054)^{\star}\end{array}$ \\
\hline$I C T \_I N V$ & & & $\begin{array}{l}-0.054 \\
(0.194)\end{array}$ & & & $\begin{array}{l}-0.048 \\
(0.274)\end{array}$ & & & $\begin{array}{l}-0.027 \\
(0.729)\end{array}$ & & & $\begin{array}{l}-0.049 \\
(0.515)\end{array}$ \\
\hline H_SKILLED & & & & $\begin{array}{c}-0.197 \\
(0.076)^{\star}\end{array}$ & $\begin{array}{c}-0.211 \\
(0.066)^{\star}\end{array}$ & $\begin{array}{c}-0.269 \\
(0.071)^{\star}\end{array}$ & & & & $\begin{array}{c}-0.287 \\
(0.077)^{\star}\end{array}$ & $\begin{array}{c}-0.301 \\
(0.080)^{\star}\end{array}$ & $\begin{array}{c}-0.454 \\
(0.082)^{\star}\end{array}$ \\
\hline W_COLLARS & & & & & $\begin{array}{l}-0.115 \\
(0.733)\end{array}$ & $\begin{array}{l}-0.097 \\
(0.787)\end{array}$ & & & & & $\begin{array}{l}-0.367 \\
(0.522)\end{array}$ & $\begin{array}{l}-0.330 \\
(0.598)\end{array}$ \\
\hline GRADUATES & & & & & $\begin{array}{l}-0.042 \\
(0.812)\end{array}$ & $\begin{array}{l}-0.041 \\
(0.837)\end{array}$ & & & & & $\begin{array}{c}-0.674 \\
(0.031)^{\star \star}\end{array}$ & $\begin{array}{c}-0.669 \\
(0.065)^{\star}\end{array}$ \\
\hline INDUSTRY & no & no & no & no & no & no & yes & yes & yes & yes & yes & yes \\
\hline PROVINCE & no & no & no & no & no & no & yes & yes & yes & yes & yes & yes \\
\hline Obs. & 614 & 613 & 554 & 605 & 541 & 487 & 397 & 397 & 363 & 390 & 335 & 307 \\
\hline P-value & $0.000^{\star \star \star}$ & $0.000^{\star \star \star}$ & $0.000^{\star \star \star}$ & $0.000^{\star \star \star}$ & $0.000^{\star \star \star}$ & $0.000^{\star \star \star}$ & $0.000^{\star \star \star}$ & $0.000^{\star \star \star}$ & $0.000^{\star \star \star}$ & $0.000^{\star \star \star}$ & $0.001^{\star \star \star}$ & $0.002^{\star \star \star}$ \\
\hline Pseudo R2 & 0.133 & 0.143 & 0.147 & 0.140 & 0.142 & 0.157 & 0.272 & 0.286 & 0.296 & 0.281 & 0.300 & 0.392 \\
\hline
\end{tabular}

